Review

\title{
Engineering Biomaterials to Guide Heart Cells for Matured Cardiac Tissue
}

\author{
Yongjun Jang, Yongdoo Park * $\mathbb{D}$ and Jongseong Kim * \\ Department of Biomedical Sciences, College of Medicine, Korea University, Seoul 02841, Korea; \\ jyj727@korea.ac.kr \\ * Correspondence: ydpark67@korea.ac.kr (Y.P.); envokim72@korea.ac.kr (J.K.); \\ Tel.: +82-10-4260-6460 (Y.P.); +82-10-8858-7260 (J.K.)
}

Received: 3 September 2020; Accepted: 24 September 2020; Published: 27 September 2020

\begin{abstract}
The extracellular matrix (ECM) is needed to maintain the structural integrity of tissues and to mediate cellular dynamics. Its main components are fibrous proteins and glycosaminoglycans, which provide a suitable environment for biological functions. Thus, biomaterials with ECM-like properties have been extensively developed by modulating their key components and properties. In the field of cardiac tissue engineering, the use of biomaterials offers several advantages in that biophysical and biochemical cues can be designed to mediate cardiac cells, which is critical for maturation and regeneration. This suggests that understanding biomaterials and their use in vivo and in vitro is beneficial in terms of advancing cardiac engineering. The current review provides an overview of both natural and synthetic biomaterials and their use in cardiac engineering. In addition, we focus on different strategies to recapitulate the cardiac tissue in 2D and 3D approaches, which is an important step for the maturation of cardiac tissues toward regeneration of the adult heart.
\end{abstract}

Keywords: extracellular matrix (ECM); biomaterials; cardiac tissue engineering; tissue regeneration; cardiomyocytes; cardiac spheroids; 2D pattern; 3D printing; surface coating; cardiac scaffolds; maturation

\section{Introduction}

The extracellular matrix (ECM) plays a key role not only in maintaining the structural integrity of tissues, but also in transmitting biological and biochemical signals to the cells that mediate cellular dynamics, including proliferation, differentiation, migration, and apoptosis [1]. ECM-cell interactions are pivotal in providing a suitable environment for cells and to make each organ function normally. The change in ECM composition, also known as a part of ECM remodeling, is tightly related with development, disease, and regeneration [2]. In particular, the development of heart tissue is accompanied by varying the composition of the ECM depending on the development age. These changes have a great influence on the formation of the heart structure and its function [3,4]. Thus, understanding ECM-cell interactions and designing appropriate in vitro models and scaffolds are extremely desirable in order to apply ECM in the field of cardiac tissue engineering and regenerative medicine as biomaterials.

Fabricating cardiac tissues in vitro requires ECM as well as cardiac cells, such as cardiomyocytes, cardiac fibroblasts, and endothelial cells $[5,6]$. The construction of mature heart substitutes and tissues in vitro requires precise control of ECM-cell interactions for the cell alignment, maturation, and contraction of the cardiac cells [7]. In particular, maturation of stem cell-derived cardiomyocytes with an adult phenotype is challenging to apply in tissues in drug discovery [8]. Therefore, fabricating ECM for a scaffold, which mimics heart tissue in terms of composition, mechanical properties, and geometry, is essential to achieving mature cardiac tissue. On the other hand, combining and 
assembling heart cells, i.e., cardiomyocytes and cardiac fibroblasts in engineered cardiac tissues, is essential to form functional cardiac tissues that synchronize the contractility of cells in the engineered tissues [9]. Thus, micro- and macroscale understanding of cell-cell interactions is necessary, which is the purpose of various two-dimensional (2D) and three-dimensional (3D) approaches (see Figure 1).

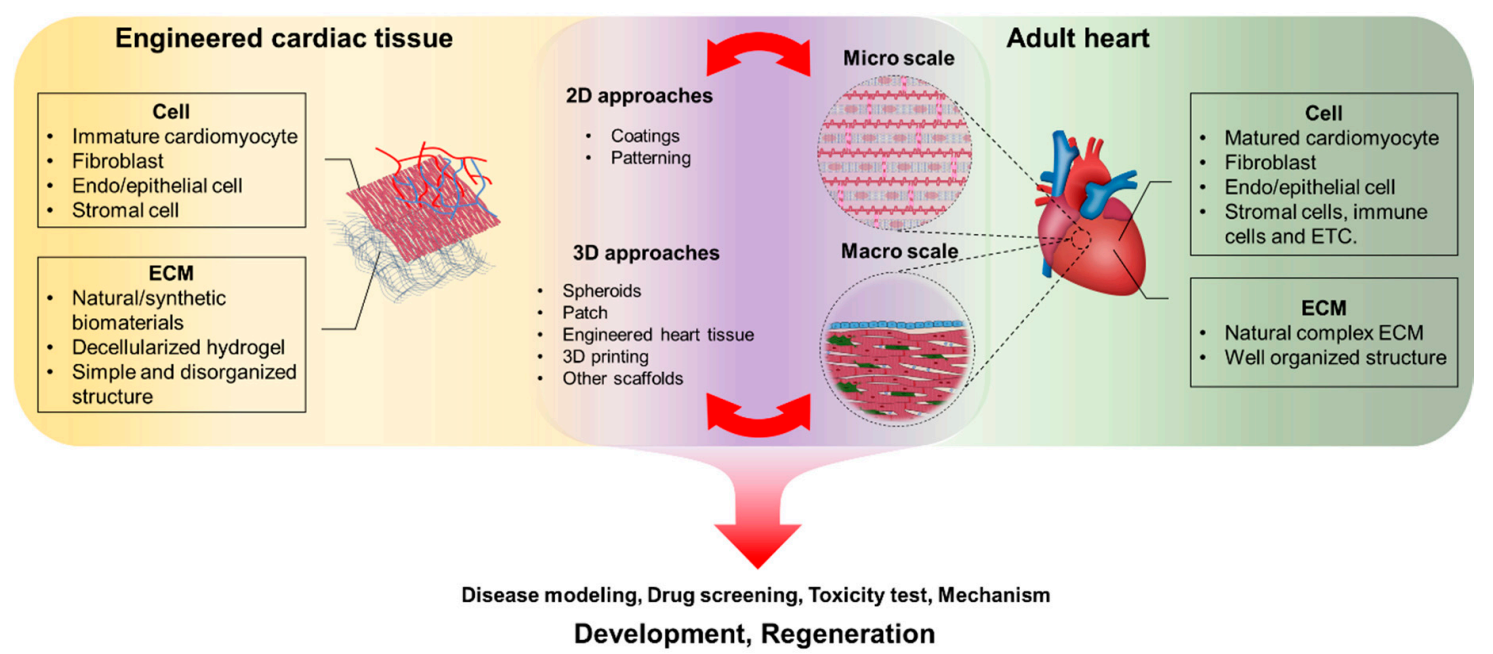

Figure 1. Different strategies to fabricate in vivo-like cardiac tissue by using cells and biomaterials.

Biomaterials have significant effects in the field of cardiac tissue engineering by providing mechanical and biochemical cues to maintain the structural and functional properties of cells or tissues [10]. The mechanical cues, including topological structures, stiffness, and various mechanical forces, facilitate the structural maturation of the heart $[7,11]$. In addition, biochemical cues such as growth factors, cytokines, and adhesion molecules induce functional maturation of cardiac cells [12]. According to the properties of the biomaterial, it can be categorized into two subtypes: natural materials and synthetic materials. Both have been extensively studied in cardiac tissue engineering since biomaterials can recapitulate the ECM of a native heart. For instance, natural biomaterials, including hyaluronan, fibronectin, and collagens, i.e., ECM compounds, have been utilized to fabricate mature cardiac tissues by mimicking the microenvironment of the human heart [13]. The main issue regarding maintaining an adequate mechanical integrity is related to the stiffness of the biomaterials, which is relatively low compared to that of the actual myocardium [14]. To overcome this limitation, synthetic materials have been developed. Synthetic materials are manufactured consistently and have better mechanical properties and tunability than natural materials [15]. However, the biocompatibility and degradation of synthetic materials can cause an inflammatory response [13]. Thus, the development of advanced natural and synthetic materials is required for the construction of mature cardiac tissues that consider the temporal and spatial complexity of the natural heart.

Conventional two-dimensional (2D) culture on a flat surface using plastic plates, dishes, or flasks is an effective culture method for cell expending or simple testing under defined conditions [16]. Biomaterials have been utilized to functionalize a flat surface to increase cell adhesion and thus to observe changes in cells in a specific environment. Limited cell morphology and polarity in 2D culture systems hamper the construction of sufficient interactions between cells, or cells and biomaterials. To reduce the gap between the 2D culture and the native tissue, a three-dimensional (3D) culture system has been developed, which allows us to mimic the in vivo environment closely. For example, organoids, i.e., 3D cell assemblies that are differentiated from stem cells, demonstrate a unique morphology depending on the development of spatiotemporal cues, such as cell-ECM and cell-cell interactions, which are the hallmarks of three-dimensional tissues [17]. Furthermore, 3D cardiac tissues composed of cardiomyocytes with biomaterials are superior when structurally matured to 2D cardiac cells, and their response to drug molecules is similar to in vivo responses $[18,19]$. Thus, the formation of 
three-dimensional myocardial tissue similar to myocardial cells can provide more accurate results in drug evaluation, disease modeling, and transplantation.

Biomaterials have been the object of research for the past few decades in terms of replacing or enhancing the ECM to mediate tissue morphology and function [20-22]. In this review, we introduce the biomaterials according to the types of natural and synthetic materials used and their use in tissue engineering and regeneration. For the search of literatures, we mainly used the google scholar and the PubMed database. In particular, we focus on biomaterials used in the field of both 2D and 3D cardiac tissue engineering, and a number of strategies to recapitulate the cardiac tissue.

\section{Materials for Cardiac Tissue Engineering}

\subsection{Natural Materials}

\subsubsection{Collagen}

Collagen is one of the most abundant proteins among ECM components, and it plays a key role in not only maintaining the structural integrity of tissues, but also providing a biologically suitable environment for cells [23]. Although 29 different types of collagen have been studied so far [24,25], collagen type I has been extensively used as a scaffold material for tissue engineering. The merit of using collagen type I comes from its low immunogenicity [26] and the fact that it is also abundant and structurally important in various organs and structures in the body, including bone [27,28], cartilage [29,30], tendon [31,32], blood vessels [27,33], skin [34], the heart [35], and nerves [36,37]. Collagen type I is composed of two alpha 1 chains and one alpha 2 chain [38] and has a hierarchical structure where collagen molecules gather to form collagen fibril, following the formation of collagen fibers $[39,40]$ (Figure 2). The fibrillar structure and mechanical properties of the tissue are dependent on the fiber density and spatial alignment in three dimensions, which affects cell migration, morphogenesis, regeneration, and differentiation $[26,41,42]$.

A

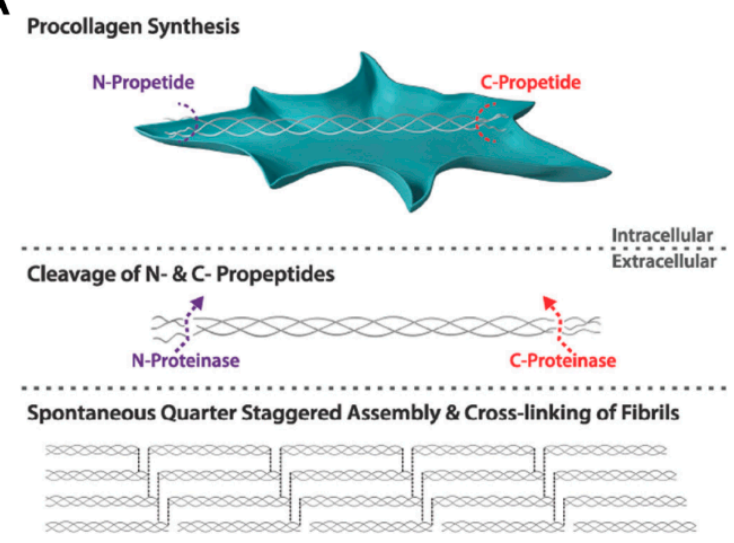

B

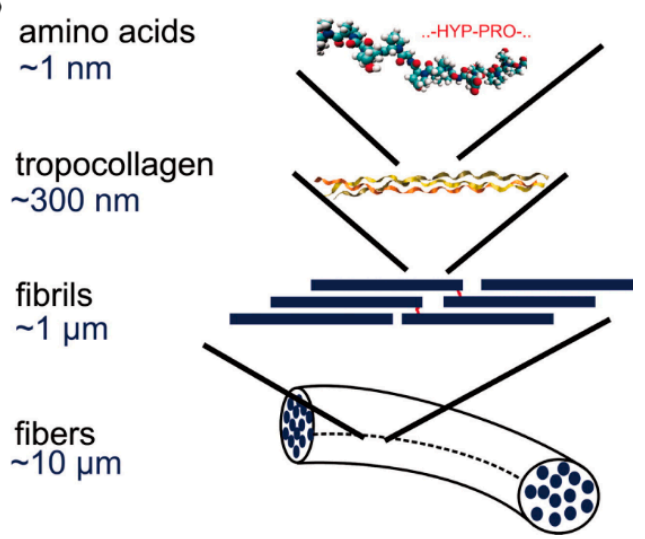

Figure 2. (A) Biosynthesis pathway and (B) hierarchical structure of collagen. Reprinted from [25,40]. Copyright (2018) John Wiley \& Sons, Inc. and (2006) National Academy of Sciences.

\subsubsection{Fibrin}

Fibrin is an example of a protein monomer that is formed by the cascade reaction of fibrinogen and thrombin in response to physiological injury such as bleeding [43]. The formation of the fibrin network plays an important role in various pathological processes, including inflammatory response, hemostasis, fibrinolysis, and wound healing [44]. Polymerized fibrins are cooperative with fibronectin, factor XIII, angiogenic factors, and platelets, which yields a hemostatic plug formation that enables them to anchor various cells at the site of injury. In particular, factor XIII is converted to factor XIIIa (transglutaminase) by thrombin and $\mathrm{Ca}^{2+}$, which triggers crosslinking of a fibrin mesh between its glutamines and 
lysines [45] (Figure 3). The crosslinked fibrin network can be degraded by proteases, such as plasmin and metalloproteinases released from cells. It has weak mechanical properties compared to other natural materials. To suppress the high degradability of the fibrin network, a bovine fibrinolytic inhibitor such as aprotinin can be used in in vitro experiments, and alternatively, a combination with other biomaterials has been shown not only to limit the degradability, but also to enhance the mechanical properties.

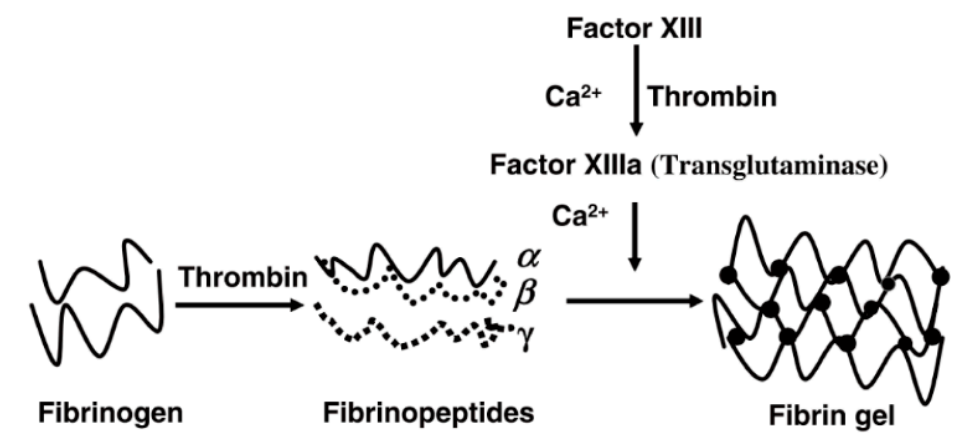

Figure 3. The process of fibrin gel formation through the reaction of fibrinogen and thrombin. Reprinted from [45]. Copyright (2008) IOP Publishing.

\subsubsection{Fibronectin}

Fibronectin is an essential component of the extracellular matrix, which regulates cellular activities including adhesion and migration [46]. Fibronectin is stabilized when circulating in the blood plasma and exists as an inactive conformation, but in fibrillar form, it turns into an active conformation in various states that provides binding sites for other proteins such as fibrin, collagen, and integrins. This multidomain protein composed of three repeat modules, type I, II, and III, has multiple binding sites including the RGD (Arg-Gly-Asp; arginine, glycine, and aspartate) domain, the collagen-binding domain, and the fibrin-binding domain, respectively [47] (Figure 4). In particular, fibronectin-integrin interaction is an important process that connects the cell surface to the actin cytoskeleton inside the cell and seems to play an essential role in matrix formation and remodeling [48].

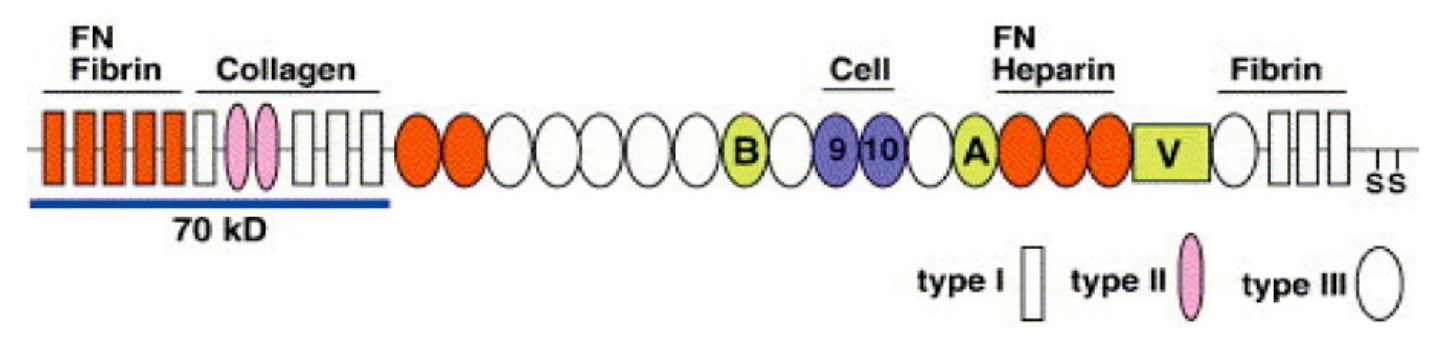

Figure 4. Schematic view of the structure of fibronectin. Binding sites for other proteins and three repeat modules are indicated. Reprinted from Ref. [48]. Copyright (2005) Elsevier.

\subsubsection{Matrigel}

Matrigel, extracted from Engelbreth Holm Swarm (EHS) tumor cells, is commonly used as a basement membrane matrix to support cell morphogenesis [49], differentiation [50,51], tumor growth [52,53], and maintain the stem cell stemness [54,55]. The major components of Matrigel are laminin, collagen type IV, and entactin which contain peptide residues for binding to structural proteins that transduce a number of biological signals and functions [55]. In addition, several growth factors, such as FGF (fibroblast growth factor), EGF (epidermal growth factor), TGF (transforming growth factor), IGF (insulin-like growth factor) and PDGF (platelet-derived growth factor), are also known to be present in Matrigel [56]. This natural ECM-based gel can provide an in vivo-like environment for 
in vitro cell culture experiments [57,58] and biological assays [59,60] (Figure 5). However, Matrigel is composed of multiple components and varies between batches and products, and these characteristics often increase the uncertainty of experimental results.

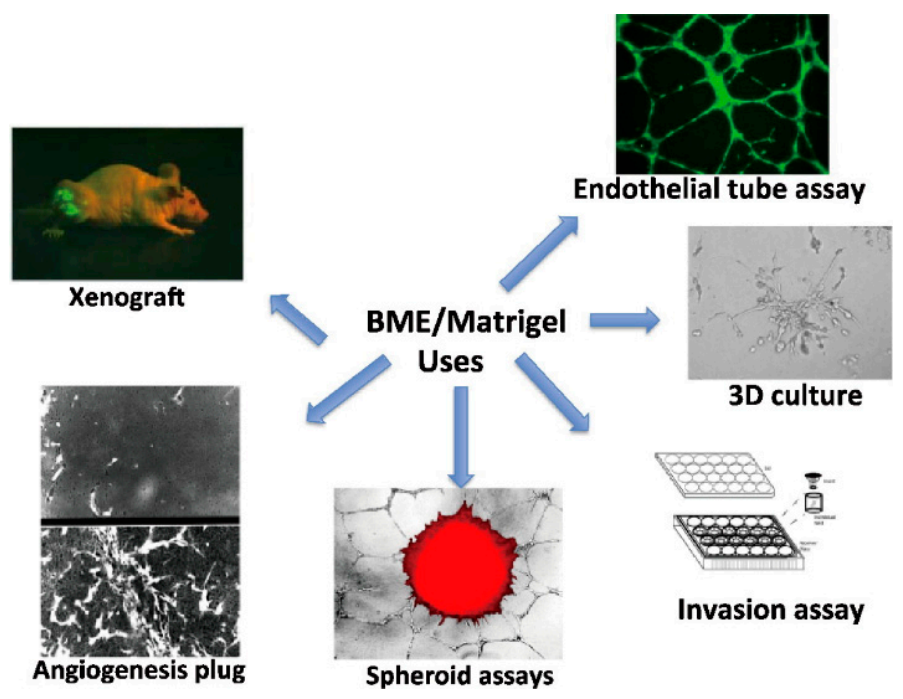

Figure 5. A schematic diagram of in vitro and in vivo assays in which Matrigel is mainly used. Reprinted from [56]. Copyright (2014) Elsevier.

\subsubsection{Decellularized ECM}

Since biomimetic scaffolds containing natural materials such as ECM play a central role in regulating cell function as well as tissue regeneration, the development of advanced scaffolds is highly necessary in regenerative medicine to replace tissues and organs [61,62]. The process of specifically removing cells in order to obtain native ECM from native tissue or organ is called decellularization, and its product, i.e., decellularization ECM (dECM), contains structural and functional proteins and glycosaminoglycan that contribute to the cellular activity, such as cell mitogenesis, chemotaxis, and differentiation [63]. The type for decellularization method is divided into three types: chemical, enzymatic, and physical, and the optimal procedure for harvesting AECM with a fully preserved structure and composition depends on the tissue characteristics including thickness and density [64]. Although dECM is an example of biologically inspired scaffolds close to native tissue, its use is limited by $\mathrm{dECM}$ variations according to different donors and the availability of tissue [63]. Despite the limitations, it is beneficial to obtain dECM-based scaffolds through whole organ or tissue decellularization, which allows for extensive application of dECM in the field of tissue engineering (Figure 6).

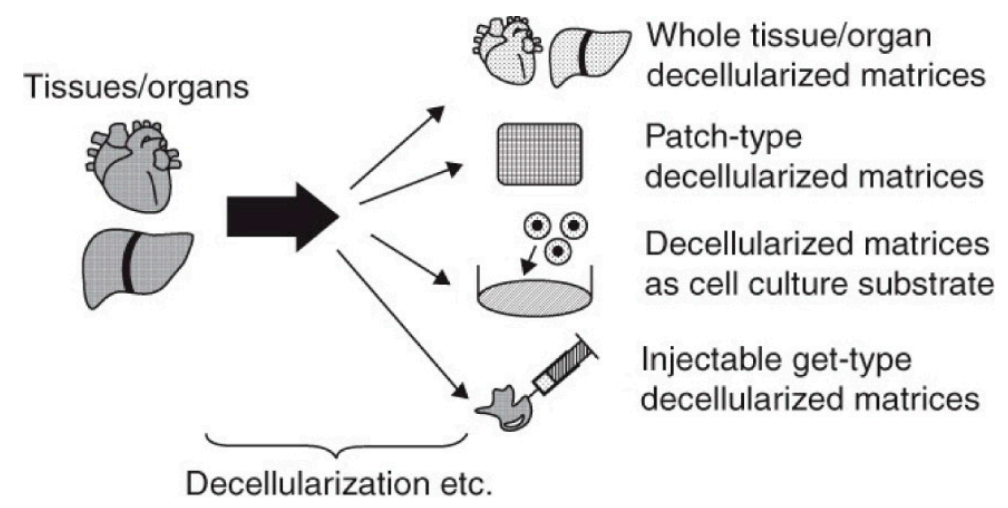

Figure 6. Different applications of decellularized matrices from tissues and organs. Reprinted from [63]. Copyright (2010) Informa UK Limited. 


\subsection{Synthetic Materials}

\subsubsection{Polycaprolactone (PCL)}

Polycaprolactone (PCL), composed of repeating units of hexanoate, is one of the most studied synthetic polymers in relation to tissue engineering through various formulations [65]. PCL is mainly synthesized by condensation of 6-hydroxycaproic (6-hydroyhexanoic) acid and ring-opening polymerization of $\varepsilon$-caprolactone using a catalyst. PCL is biodegradable through the hydrolysis of an aliphatic polyester linkage, and the degradation rate is quite slow due to the five hydrophobic- $\mathrm{CH}_{2}$ moieties of repeating units [66] (Figure 7). The mechanical properties of PCL can be adjusted according to molecular weight and degree of crystallinity [67]. As to achieve enhanced mechanical properties, biocompatibility, and to control the degradation time, PCL has been used in combination with natural polymers and other synthetic polymers.

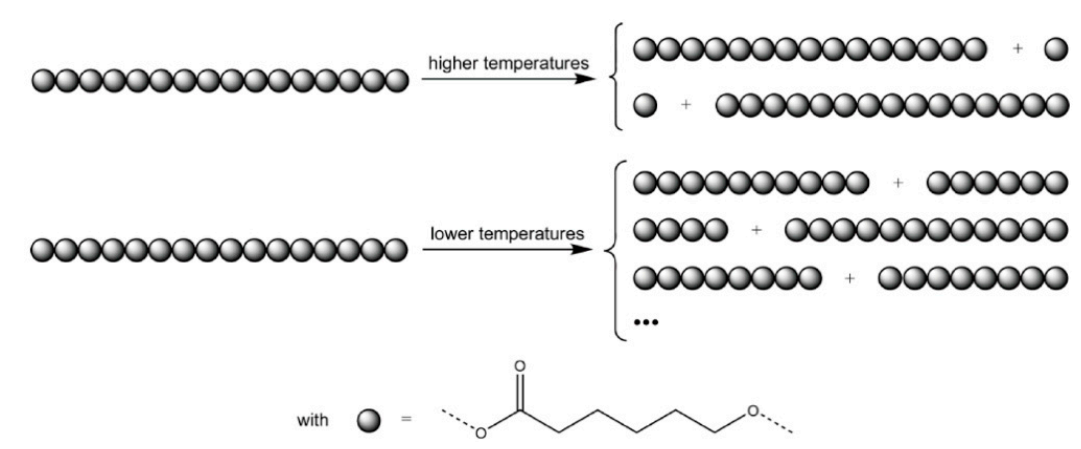

Figure 7. The chemical structure of polycaprolactone (PCL) (sphere) and degradation of PCL dependent on temperature. Reprinted from [67]. Copyright (2009) The Royal Society of Chemistry.

\subsubsection{Polylactide (PLA)}

Poly (lactic acid) (PLA), an aliphatic polyester composed of $\alpha$-hydroxy acids, is a nontoxic and naturally occurring organic compound that has been widely used in the field of tissue engineering [68]. PLA was first synthesized by Carothers in 1932 by heating lactic acid under vacuum conditions. Thereafter, a number of synthetic methods for the production of PLA, such as direct condensation, enzymatic reaction, and ring-opening polymerization, have been developed. Among those methods, ring-opening polymerization of lactide in presence of metal catalysts is mostly used, which also yields the production of racemic mixture, i.e., D-PLA (PDLA) and L-PLA (PLLA), and D,L-PLA (PDLLA) $[69,70]$ (Figure 8).

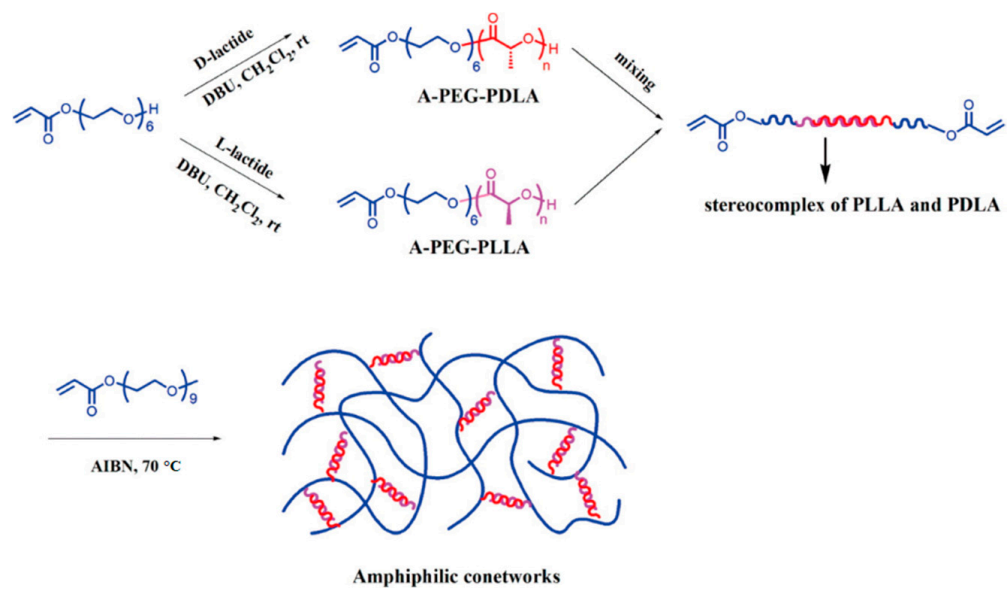

Figure 8. Illustration of amphiphilic conetworks synthesis by polylactide (PLA) stereocomplex. Reprinted from [70]. Copyright (2013) American Chemical Society. 
Direct condensation of lactic acid is another common method to produce PLA, which has a prerequisite for the removal of water during the process. PLA is biodegradable through hydrolysis of the ester bond and the degradation rate depends on the isomer ratio, processing temperature, and molecular weight. In comparison with other synthetic polymers, PLA has a high biocompatibility and processability, and it is often used with a copolymer such as PLGA (poly(lactic-co-glycolic acid)) to overcome certain limitations, such as poor toughness, the slow degradation rate, and the lack of reactive side-chain groups [71].

\subsubsection{Poly(Ethylene Glycol) (PEG)}

Poly(ethylene glycol) (PEG) is an especially hydrophilic polymer and is called polyethylene oxide (PEO) or polyoxyethylene (POE) depending on its molecular weight [72]. PEG is produced by the interaction of ethylene oxide and catalysts with water. PEG can contain water to more than $95 \%$ of the total volume [65]. Because of this characteristic, PEG is highly permissible, enabling facile diffusion of nutrients, and has cytocompatibility, so it has been widely used as a 3D cell culture system. In addition, molecules such as drugs, proteins, and therapeutic vesicles can be attached to the polymer chain of PEG via covalent and noncovalent bonds, and this process is called PEGylation [73] (Figure 9). Thus, PEG is commonly utilized in tissue engineering as well as in biomedical applications, such as drug delivery [74].

A

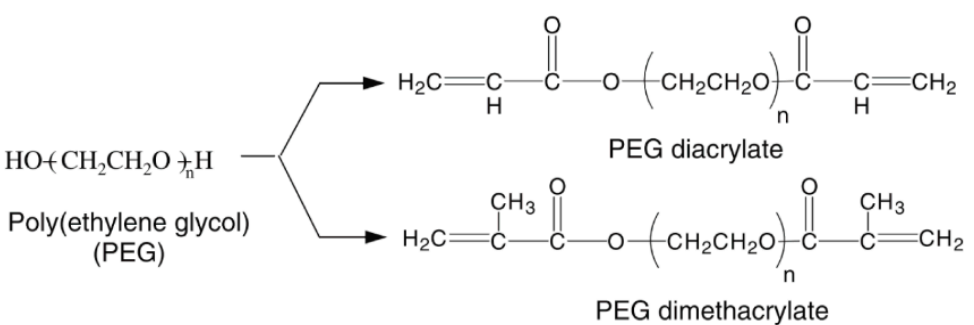

B

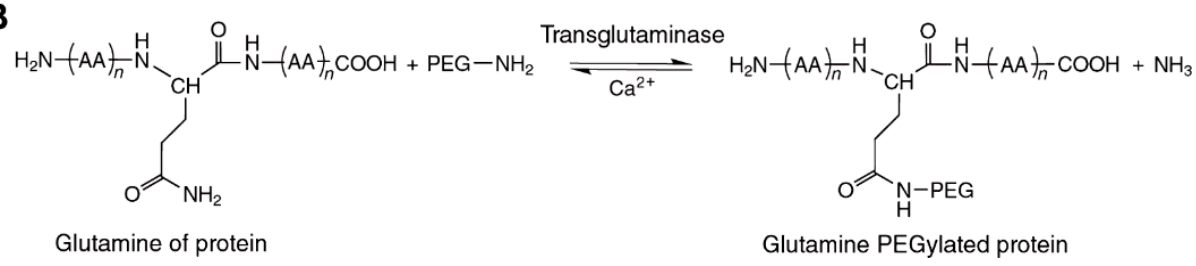

Figure 9. (A) Poly(ethylene glycol) (PEG) di(meth)acrylate synthesis from the PEG monomer to form hydrogel and (B) enzymatic PEGylation by transglutaminase. Reprinted from [72,73]. Copyright (2008) Springer Nature and (2005) Elsevier.

\section{Approaches for Cardiac Tissue Preparation}

\subsection{Two-Dimensional (2D) Culture}

\subsubsection{Coatings}

For the 2D culture of cardiomyocytes, Matrigel, collagen, and fibronectin have been mainly used as a coating material since such materials have binding sites for integrins on the surface of cardiomyocytes [75]. For instance, collagen binds to integrin $\alpha 3 \beta 1$, and fibronectin has the ability to bind to a number of integrins including $\alpha 4 \beta 1, \alpha 5 \beta 1$, and $\alpha \mathrm{V} \beta 1$. The adhesion of these substrates and cardiomyocytes affects the organization of the cytoskeleton as well as the contractility of the cardiomyocytes. As a result of analyzing the cell characteristics by culturing cardiomyocytes on collagen and fibronectin substrates, the adhesion rate of cardiomyocytes to the fibronectin is higher and actin filaments are better developed than those of collagen. Moreover, the differences have been shown to affect the contractile status of cardiomyocytes. In another study, the mechanical properties of 
cardiomyocytes on collagen and fibronectin substrates were measured by atomic force microscopy [76]. As a result, it was confirmed that the stiffness of cardiomyocytes was higher in fibronectin than in collagen, and the stiffness was higher in the case of aligned cells than in unaligned one (Figure 10). What is interesting here is that the unaligned cardiomyocytes with a fibronectin coating showed a higher stiffness than the aligned group. Although cellular stiffness is partially related with cell-cell junctions and attachments, it suggests that substrate-cell attachment is important for the mechanical properties of cardiomyocytes. Therefore, coating with appropriate materials is highly necessary to mediate the maturation and function of cardiomyocytes.
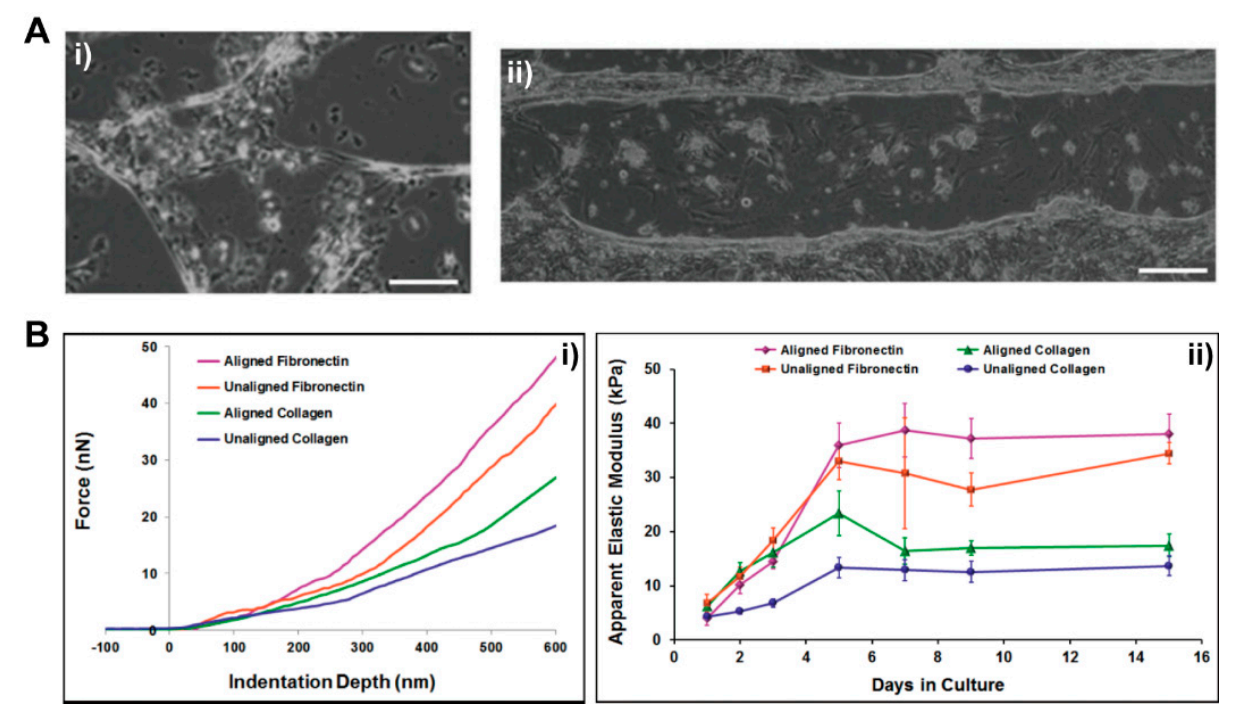

Figure 10. (A) Brightfield microscopy images of cardiomyocytes on unaligned (i) and aligned (ii) collagen matrices. (B) Measurement of force (i) and elastic moduli (ii) on different substrates. Scale bar: $20 \mu \mathrm{m}$. Reprinted from [76]. Copyright (2012) Tech Science Press.

With the purpose of mimicking the microenvironment of the heart, a number of natural materials have been explored. For example, ECM produced by cardiac fibroblast is used as a coating material for cardiomyocyte culture [77]. A study comparing the cardiac fibroblast-derived ECM to fibronectin showed that the ECM developed more cardiomyocyte cytoskeleton than fibronectin. In addition, cell adhesion and spontaneous contractility progressed rapidly in the cardiac fibroblast-derived ECM. Decellularized ECM (dECM), derived from adult rat myocardial tissue, was shown to affect cardiomyocyte differentiation [78]. It was verified by qPCR that when a cardiac-inducing cocktail, such as oxytocin, ascorbic acid, $\alpha$-tocopherol, and $\beta$-mercaptoethanol, and ECM, was used together in human adipose-tissue-derived stem cells (hADSC), the cardiac differentiation rate was significantly increased compared to either thes cytokine- or dECM-only group. These studies suggest that the use of cardiac-like ECM enabled the initiation of differentiation and development of myocardial cells, which was further enhanced when used in combination with cytokines.

Matrigel is widely used as a coating material in human embryonic stem cell (hESC) culture, but there are limitations including batch-to-batch variation and the inability to follow xeno-free trends [79]. To resolve these constraints, synthetic peptide-acrylate surfaces (PAS), chemically defined and xeno-free materials, were developed [80] (Figure 11A). hESCs cultured on PAS were shown to maintain normal karyotype and pluripotency as seen on Matrigel-coated surfaces. Herein, cardiomyocyte differentiation was well induced and long-term culture was possible. To enhance cell adhesion, the surface of poly(lactic acid) (PLA) was functionalized by poly(poly(ethylene glycol) methacrylate) and poly[N-(3-aminopropyl)methacrylamide] [81]. This functionalization allowed the attachment and contractility of both human immortalized mesenchymal stem cells (hiMSCs) and human-induced 
pluripotent stem cells (hiPSCs) to be improved. These studies showed that synthetic materials that have a high tunability can replace a part of ECM function by providing a suitable environment for cells.

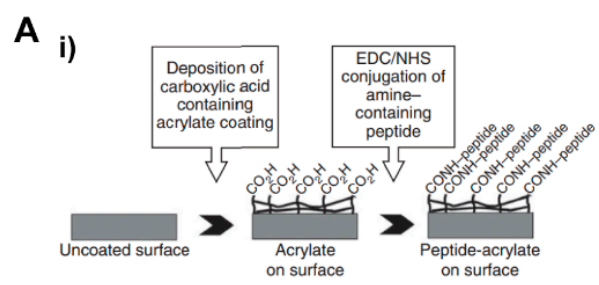

$B_{\text {i) }}$

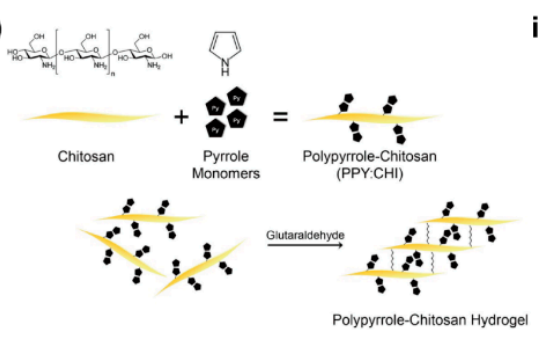

ii)

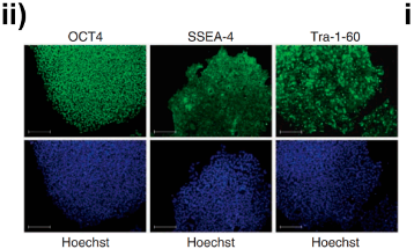

ii)

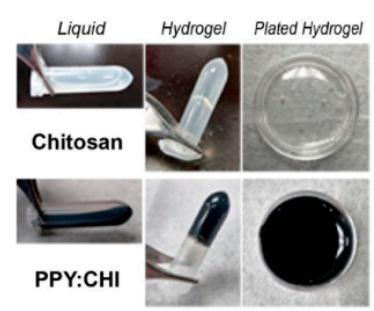

iii)

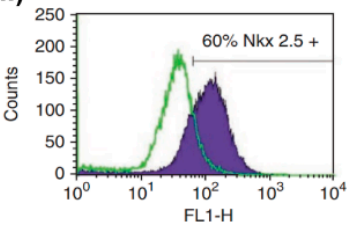

iii)

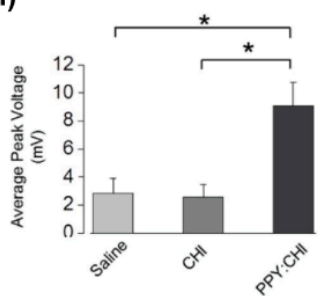

Figure 11. (A) Treatment process of the peptide-acrylate surfaces (PAS) on a substrate (i), pluripotent marker image of human embryonic stem cells (hESCs) on PAS surface by immunofluorescence staining, (ii) and flow cytometry analysis for Nkx2.5, which is known as cardiomyocyte marker (iii). (B) Generating process of polypyrrole-chitosan hydrogel (i), the degree of flexibility and rigidity of polymer hydrogels to coat culture dishes (ii), and differences in electrical signal conductivity in cryoinjured myocardial scar $\left({ }^{*} p<0.05\right)$ (iii). Reprinted from [80,82]. Copyright (2010) Nature America, Inc. and (2018) Ivyspring International Publisher.

Natural materials and synthetic materials are also used together to compensate for each other's limitations, which include inadequate mechanical properties and biocompatibility for natural materials and synthetic materials, respectively. To mimic the temporal stiffness changes that occur in vitro, poly(ethylene glycol) diacrylate was used as a crosslinker in thiolated-hyaluronic acid (HA) hydrogels [14]. In particular, the molecular weight of the crosslinker was adjusted to tune the stiffness of hydrogel to a similar degree as heart muscle. When poly(ethylene glycol) diacrylate was used as a crosslinker in these thiolated-HAs, the expression of cardiac-specific markers increased threefold or more, and maturation was up to $60 \%$ more than that of a typical static polyacrylamide hydrogel. In another study, a conductive biomaterial was made by conjugating a conductive polypyrrole (PPY) to a chitosan (CHI) backbone [82]. PPY:CHI hydrogel was biocompatible and conductive, facilitating $\mathrm{Ca}^{2+}$ transient and beating of CM imaging (Figure 11B). In addition, as a result of injecting PPY:CHI into the cryoinjury of the heart, it was confirmed that the longitudinal conduction velocity recovered to a level similar to that of the normal heart.

\subsubsection{Patterning}

The function of myocardial cells is tightly related to their structure and alignment, which includes the contractility and maturation of cardiomyocytes [83]. Many researchers have used the development of 2D coating technology with tunable synthetic materials and topologies to study how geometry affects myocardial cells. As a result of culturing cardiomyocytes on a highly uniform PEG nanopillar (radius: $150 \mathrm{~nm}$, height: $400 \mathrm{~nm}$ ) produced by using ultraviolet-assisted capillary lithography, cardiomyocyte adhesion was significantly enhanced compared to that of bare the PEG control [84] (Figure 12A). Moreover, it was observed that cardiomyocytes were colonized, and self-assembled aggregates and 3D growth were also observed. In addition to a nanopillar, nanogrid or nanogroove arrays were also used. Patterning of nanogroove widths ranging from $350 \mathrm{~nm}$ to $2000 \mathrm{~nm}$ was performed using polyurethane acrylate (PUA), and nanotopographic substrates were coated with a 
self-assembling chimeric peptide containing Arg-Gly-Asp (RGD) [85]. As a result of observing the alignment changes of the cardiomyocytes on these nanogrooves, it was shown that cardiomyocyte organization and structural development were most improved in the 700-1000 $\mathrm{nm}$ range.

Since cell alignment and sarcomere formation are greatly influenced by geometry, a number of studies focused on identifying the relationship between structural maturation and the geometry of cardiomyocytes (CMs). Using a microcontact printing method, nonadherent poly(ethylene glycol) was patterned with different aspect ratios, and Matrigel and fibronectin were coated on other areas to pattern cells [86]. The cell and nuclear area were aligned along with the pattern. The interesting point here is that the alignment is dependent on width rather than aspect ratio. When the width was between about 30 and $80 \mathrm{~mm}$, it was observed that the cardiomyocytes were aligned best. In another study, imprinting primary human cardiomyocytes on polydimethylsiloxane (PDMS) substrates and culturing induced pluripotent stem cell (iPSC)-derived CMs onto that geometry enabled the simulation of the biophysical and biomechanical complexity of the heart [87]. As a result, the differentiation and maturation processes of induced pluripotent stem cell (iPSC)-derived CMs progressed rapidly. Cardiomyocytes constructed from patient-derived iPSC were also used to study the mechanism of cell alignment by geometry. When myogenic progenitor cells made of iPSC from Duchenne Muscular Dystrophy (DMD) patients were cultured on Matrigel-coated nanogrooves, the functional dystrophin alignment was almost 14 degrees worse than that of normal-iPSC-derived myogenic progenitor cells [88] (Figure 12B). When the interaction between dystrophin-associated-protein-complex (DAPC) and laminin was prevented using heparin or anti- $\alpha$-dystroglycan antibody IIH6, the myotube was aligned in the perpendicular direction of the nanogroove. Thus, these studies suggest that the physico-mechanical cues provided by geometry greatly influence the reorganization of the cytoskeletal network in CMs, and this is regulated by DAPC-mediated cytoskeleton-extracellular matrix linkage.

A

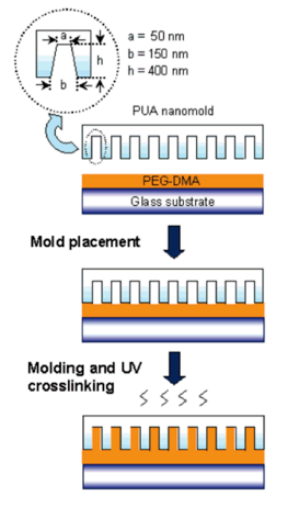

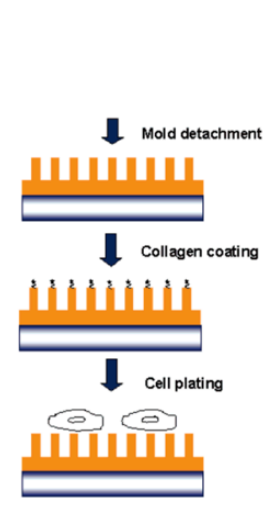

B

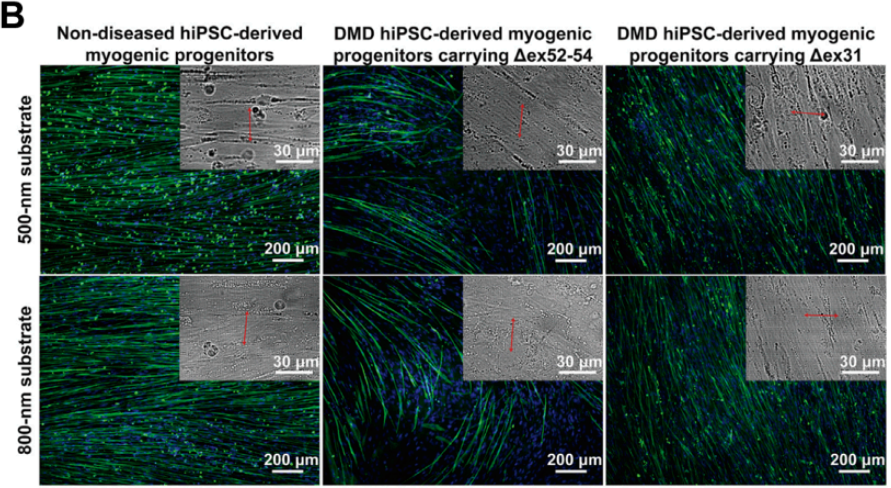

Figure 12. (A) Schematic illustration of poly(urethane acrylate) (PUA) nanopillar array mold fabrication by ultraviolet (UV)-assisted capillary lithography. (B) Difference in myotube alignment by nanogrooved substrates of the myogenic progenitors derived from Duchenne muscular dystrophy (DMD) hiPSC and normal hiPSC. Reprinted from [84,88]. Copyright (2006) American Chemical Society and (2018) Elsevier.

\subsection{Three-Dimensional (3D) Culture}

\subsubsection{Spheroids}

Spheroids are multicellular 3D models in which cells are spherically aggregated, and they have been widely investigated because they can be easily prepared without using scaffolds [89]. The common method to form spheroids by aggregation is to utilize gravity, i.e., the hanging-drop method and the non-adhesive surface method. Cardiac spheroids differ significantly from 2D cardiac tissues in the structure, function, and morphology of cardiomyocytes, which also influences cardiac function and maturation [90]. In 2D cardiac tissues, cardiomyocytes are mostly scattered and a small portion of the adjacent cells form cell-cell junctions, while 3D spheroids allow cell-cell junctions to form not only 
with the cells next to them, but also with the cells around them, in three dimensions. Furthermore, cardiac spheroids can be prepared with other types of cells such as fibroblasts and endothelial cells, which are composed of a native heart matrix, potentiating their use for disease modeling and drug screening [91]. In a cardiac spheroid formed by mixing iPSC-derived myocardial cells with fibroblasts and endothelial cells, cell-cell junctions and extracellular matrices, such as fibronectin, collagen IV, and laminin, were well formed in the spheroid, mimicking the in vivo cardiac environment [92]. Herein, the cardiac toxicity was evaluated by treating cardiac spheroids with increasing concentrations of doxorubicin, which is widely known to be toxic. The effect of nitric oxide synthase (NOS) inhibitor L-NIO (nitroimino-L-ornithine) on the cardiac spheroids was also measured, which attenuates the toxicity of doxorubicin. These results suggest that cardiac spheroids are a powerful platform on which to perform toxicity tests.

The gravity-assisted method, however, can only regulate the number and type of cells, commonly yielding unsynchronized contraction of cardiac organoids. To overcome this limitation, eclectically conductive materials can be added during the preparation of spheroids. Cardiac spheroids that utilize electrically conductive silicon nanowires (e-SiNW) for the preparation demonstrate synchronized beating, enhanced contraction, and structural maturation of cardiomyocytes [93] (Figure 13). In another study, the effect of cell numbers (from 500 to 7000) on spheroids was evaluated, which suggests that a spheroid composed of 3000 cells can form the best cell-cell junction without core necrosis due to an insufficient oxygen supply [94]. These studies imply that cardiac spheroids can be improved by adding functional materials such as conductive materials and modulating the number of cells per spheroid. Advancement in the field of cardiac spheroids will be beneficial for their use in disease modeling and drug screening.

A

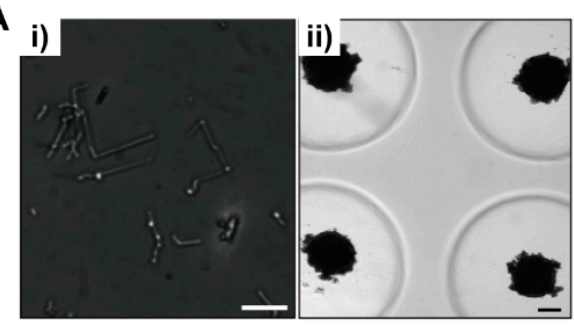

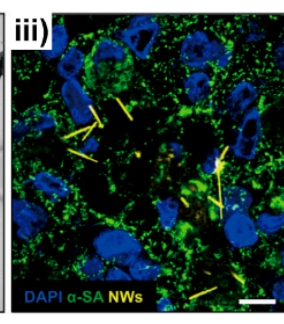

B

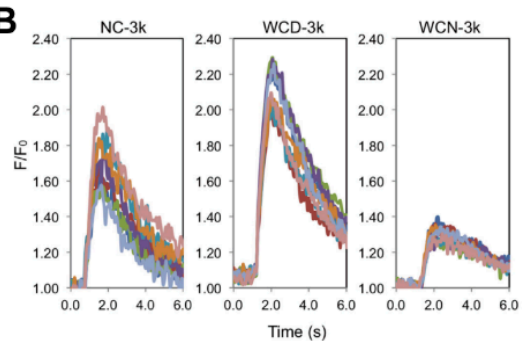

Figure 13. (A) Representative image of silicon nanowires (i), silicon nanowired (e-SiNW) human cardiac spheroids, (ii) and immunofluorescence image of a frozen section of spheroids (Blue-DAPI; Green-alpha sarcomeric actinin; Yellow-silicon nanowires) (iii). (B) Measurement of Calcium transient of spheroids by fluorescence intensity (NC-without e-SiNWs; WCD-with doped SiNWs; WCN-with undoped SiNWs). Scale bar: $10 \mu \mathrm{m}$ for ((A) i and iii), $100 \mu \mathrm{m}$ for ((A) ii). Reprinted from [94]. Copyright (2018) American Chemical Society.

\subsubsection{Cardiac Patches}

Cardiac patches, i.e., laboratory-grown heart tissue, have been studied in relation to the treatment of heart failure, where cardiac cells and biomaterials are fabricated to form a patch that is applied to the heart surface [95]. Since the cardiac patch is designed for therapeutic purposes, human pluripotent stem cell-derived myocardial cells and FDA (food and drug administration)-approved biodegradable, biocompatible materials are mainly used as scaffold materials [96]. Cardiac patches, by utilizing fibrin gel, hESC-derived CM, and a hexagonal mold, were shown to mature in the direction of the hexagonal pattern, resulting in an even alignment and increased length of sarcomeres compared to those of 2D cultured tissues [97]. The cardiac patches also provided higher conduction velocities (CVs) and gene expression associated with contractile functions, such as CTnT (cardiac troponin T), $\alpha \mathrm{MHC}$ (myosin heavy chain, $\alpha$ isoform), CASQ2 (calsequestrin-2), and SERCA2 (sarco/endoplasmic reticulum $\mathrm{Ca}^{2+}$-ATPase 2), showing that $3 \mathrm{D}$ heart patches could facilitate drug screening and cell 
therapy. Furthermore, modulating cell-cell junctions by combining fibroblasts and cardiomyocytes during cardiac patch fabrication enhances the maturation and synchronization of cardiac tissues. The cardiac patch, fabricated in a layered format of hPSC-derived CMs and cardiac fibroblast using a layer-by-layer (LBL) method, showed improved synchronization of cardiac beating compared to a cardiac patch fabricated using a mixture of those cells [98]. In the following study, the accordion-like honeycomb (ALH) pattern was engaged with the LBL-based cardiac patch. The results show that cardiac cells were aligned with the pattern and highly matured in the LBL-layered cardiomyocyte and cardiac fibroblast group [9]. In another study, a cardiac patch was fabricated using collagen, i.e., a clinically approved material, and the electrospinning method to construct a substrate by controlling the deposition of polymer fibers using an electric field [99]. They reported that cardiomyocytes matured well and the patch degraded well over time in its implantation in the surface of a mouse heart [99].

The cardiac patch made of natural materials, however, is not enough to acquire the mechanical strength and conductivity in comparison to those of a native heart. To achieve the preferred properties, rigid synthetic polymers were used together with natural materials to prepare the cardiac patch. The cardiac patch, prepared with polycaprolactone (PCL) in gelatin-chitosan hydrogel, was shown to be biodegradable with increased stiffness, improving surgical handling, suturability, and initial tensile strength [100]. A cardiac gel, i.e., a cryogel, using polypyrrole (Ppy) nanoparticles, gelatin-methacrylate, and poly (ethylene glycol) diacrylate was also constructed and applied to the heart [101]. The cardiac patch demonstrated increased expression of $\alpha$-actinin and connexin-43 genes, following the synchronous contraction of cardiomyocytes. When applied to the MI-affected rat model, the cardiac patch not only increased cardiac function, but also reduced infarct size by $42.6 \%$. To improve electrical conductivity and mechanical stiffness, gold nanorod (GNR)-incorporated gelatin methacrylate (GelMa) hybrid hydrogel was used [102] (Figure 14). The cardiac patch, prepared by using GelMA-GNR hybrid hydrogel, presented improved cardiomyocyte adhesion, viability, and metabolic activity, in which cardiac-specific markers such as sarcomeric $\alpha$-actinin and connexin- 43 were clearly expressed. In addition, it showed that rhythmic contraction, i.e., synchronous beating of the cardiac patch, was significantly enhanced compared to that of the pure GelMA hydrogel. Therefore, these studies suggest that biomaterials could increase cardiac patch function and maturity when used with synthetic materials to compensate for the mechanical properties of natural materials.

A

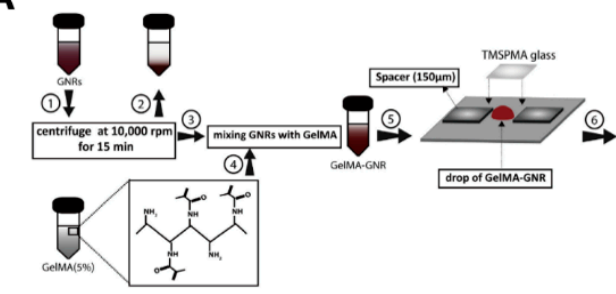

$\mathbf{C}_{\text {i) }}$

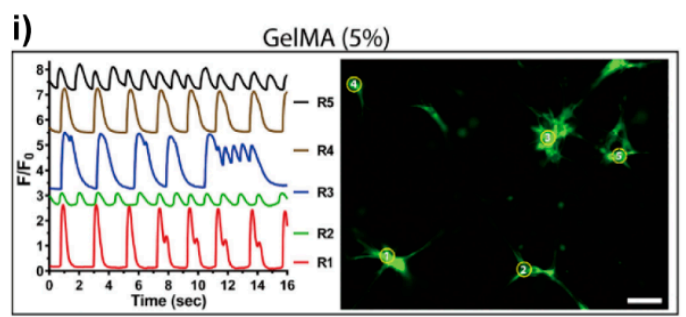

B
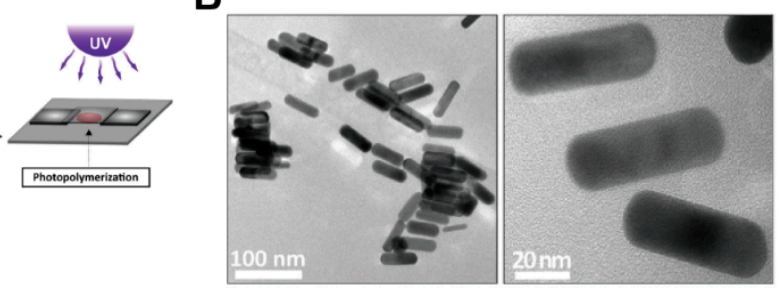

ii)

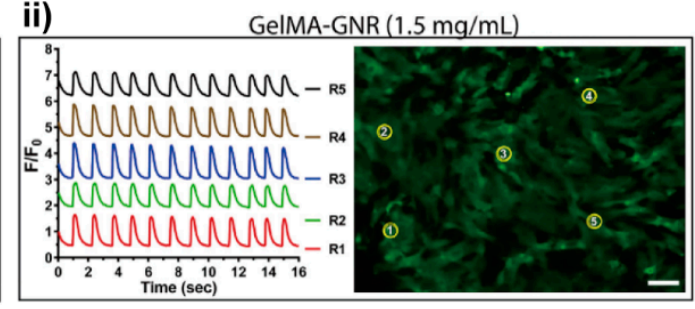

Figure 14. (A) Fabrication of gelatin methacrylate (GelMA)-gold nanorod (GNR) hybrid hydrogels and transmission electron microscopy (TEM) image of GNRs (B). (C) Calcium transient signals by measurement of intensity within cultured cardiomyocyte for (i) GelMA (5\%) and (ii) GelMA-GNR (1.5 mg/mL). Scale bar: $100 \mu \mathrm{m}$ for (C). Reprinted from [102]. Copyright (2016) Elsevier. 


\subsubsection{Rod-Shaped Engineered Heart Tissues}

Engineered heart tissue (EHT) has been developed for in vitro models and cell-based cardiac regeneration to determine the toxicity and validity of target molecules [19]. The rod-shaped EHT, created by placing two flexible silicone posts in a rectangular casting mold, has the advantage of inducing alignment by itself and measuring the contractile force of the myocardial tissue by calculating the distance of the silicone pillar [103]. In EHT prepared using collagen as a scaffold, the degree of cardiomyocytes alignment and the amount of matrix fibers increased about twofold with uniaxial mechanical stress, resulting in improved myofibrillogenesis and sarcomeric banding [104]. The hypertrophy and proliferation rate of the cardiomyocytes were increased by 2.2 times and $21 \%$, respectively, under additional cyclic stress conditions. In addition, when the endothelial cells and the interstitial cells were used in combination, the formation of vascular structures was increased by 10-fold. In the process of EHT formation, endothelial cells and stromal cells in addition to cardiomyocytes have an effect on structural maturation, such as increased function of myocardial tissue and vessel formation [105]. Although epicardium cells play a relatively unclear role, recent studies showed that epicardial cells have an enhanced effect on the structure and function of cardiac tissues. In EHT made from cardiac epithelial cells and hESC-derived myocardial cells, the contractility, muscle fiber structure, and calcium handling of EHT were all improved. Furthermore, when this EHT was implanted into myocardial infracted rat hearts, the heart graft size was reduced, suggesting a novel method for heart repair [105].

In addition to collagen, fibrin gels have been used as a scaffold of EHTs. As a result of histologically and functionally analyzed fibrin gel-based rod-shaped EHT, the sarcomere organization, alignment, and frequent mitochondria of human pluripotent stem cell (hPSC)-CM were well developed [106]. Furthermore, the analysis of systematic contractility showed that EHT is a useful platform to perform preclinical drug testing and disease modeling by measuring the responses to physiological and pharmacological regulators. Since then, EHT has been widely applied for drug screening. For instance, atrial EHT with cardiomyocytes of an atrial phenotype allows the effectiveness of atrium preclinical drug screening to be evaluated [107]. The human skeletal muscle disease model was developed using EHT and iPSCs derived from patients with diseases such as Duchenne, limb-girdle, and congenital muscular dystrophies [108] (Figure 15). EHT has been further studied for various types of disease modeling, including mutation of iPSC-derived cardiomyocyte [109] and afterload disease [110].

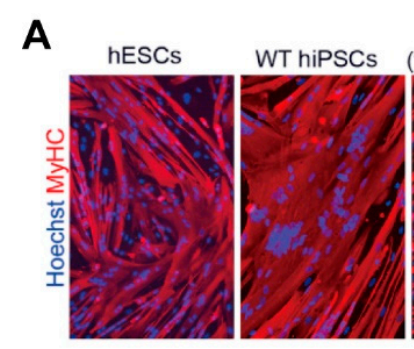

B

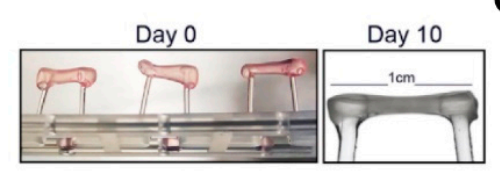

WT hiPSCs

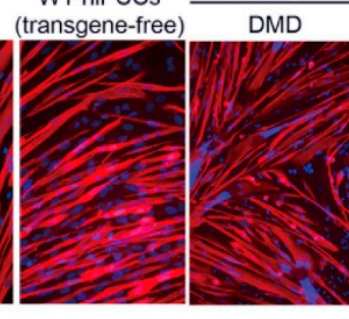

C

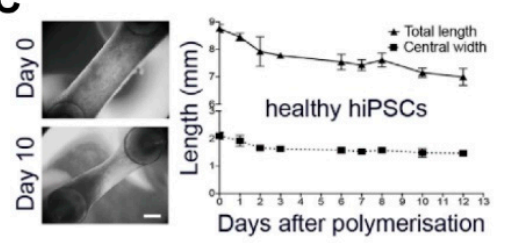

Muscular Dystrophy hiPSCs

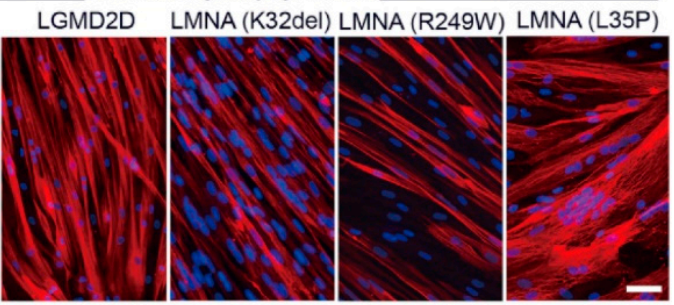

D Hematoxylin \& Eosin

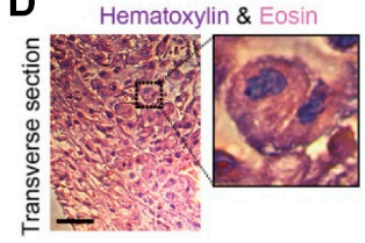

Figure 15. (A) Fabrication of a fibrin hydrogels-based engineered heart tissue (EHT) 3D culture system using multiple hPSC line-derived skeletal myotubes and Duchenne muscular dystrophy (DMD) patient-derived skeletal myotubes. Representative images of the EHT (side-view) (B), gel remodeling by time, (C) and H\&E staining. Scale bar: $100 \mu \mathrm{m}$ for (A,D), $1 \mathrm{~mm}$ for (C). Reprinted from [108]. Copyright (2018) Elsevier. 


\subsubsection{D Bioprinting for Cardiac Tissue Preparation}

In the past decades, the emergence of the biofabrication technique has had a profound effect on the development of cardiac tissue engineering, however, it remains a challenge to assemble complex structures and compositions like native myocardium. Three-dimensional bioprinting has been highlighted as a technique capable of rapidly producing complex tissues. In 2D, bioprinting has been used as a guidance cue for cell alignment. Hydrogel, patterned by bioprinting, has served as a guide for the alignment of CMs [111]. In addition, in the process of fabricating microphysiological systems (MPS), 2D microarchitectures produced by 3D printing facilitate the self-assembly of cells [112].

Bioprinting to construct 3D tissue mainly uses the microextrusion method, which expels bioink and cells through a small nozzle. Alginate hydrogel and human cardiac-derived cardiomyocyte progenitor cells were mixed and printed in a lattice pattern, showing a practical cell viability of $90 \%$ [113] and the expression of cardiac transcription factors such as Nkx2.5, Gata-4, and troponin T. 3D printed heart tissue, utilizing hyaluronic acid/gelatin (HA/gel), was also prepared and implanted into a myocardial infarction mouse model [114]. The transplanted cardiac tissue was stable for long-term culture, resulting in increased expression of the cardiac and vascular differentiation markers. Therefore, 3D printed cardiac tissue hints at the possibility of being applied in vivo. As a result of the development of 3D printing technology, natural materials with weak physical properties such as fibrin gel and decellularized ECM have been successfully used as bioinks $[115,116]$ (Figure 16). The 3D cell printing system with multiple printing nozzles enable the formation of a cardiac patch with good alignment and more complex structures. However, there is a limitation in that it is difficult to fabricate thick structures due to the low mechanical properties of natural materials. To improve the mechanical and biological properties of natural materials, synthetic materials have been used as bioinks. The composite scaffold composed of polycarprolactone (PCL) and carbon nanotube (CNT) increased the elastic modulus and hardness depending on the ratio of CNTs, while biodegradation was achieved using pseudomonas lipase enzymatic media [117]. These results showed that PCL-CNT composite scaffolds have potential in the field of cardiac tissue engineering. In another study, the conductivity was increased by adding gold nanorods (GNR) to gelatin methacryloyl (GelMA)-based bioink [118]. The 3D printed GNR-GelMA constructs caused the cardiac cells to adhere and organize better than GelMA scaffolds, and the GNRs acted as an electrical bridge to induce synchronized contraction.

In order to form a complex structure, which is the advantage of 3D printing, the appropriate mechanical strength of bioink is a prerequisite in real-world applications. Solution-based and melt-based electrohydrodynamic (EHD) printing techniques have been developed to simulate the hierarchical microarchitecture of native myocardium [119]. Polycaprolactone (PCL) was used as a contact cue by printing with microfibrous scaffolds, and sub-microscale conductive fibers were printed along PCL scaffolds to increase conductivity and improve cellular adhesion and the proliferation capacity. It was confirmed that primary cardiomyocytes were aligned according to multiple layers, and cardiomyocyte-specific gene expression and synchronous beating behavior were also increased compared to pure microfibrous scaffolds. Recently, 3D-printed, thick cardiac patches were developed that can be customized according to patient. Herein, a decellularized bioink prepared using the omentum obtained from a patient and the structure of the patient's heart analyzed by CT imaging were utilized to form the cardiac patch of cardiomyocyte and endothelial cells with two different nozzles [120]. In particular, decellularized bioink was used for the cardiomyocyte nozzle, and gelatin was used as the sacrificial ink for the endothelial cell nozzle to successfully form a complex structure in which blood vessels were formed. This result suggests the potential application of the 3D printing method in personalized medicine, implying that it can be used in various fields, such as tissue and organ production and anatomical structure production. 
A

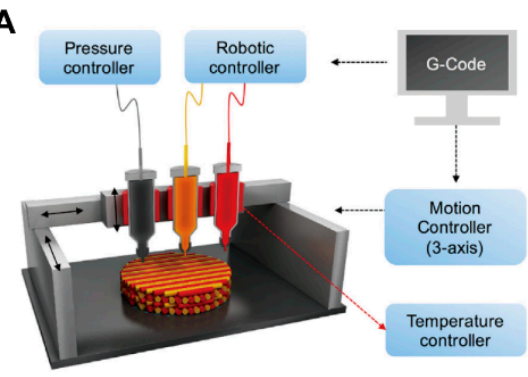

B

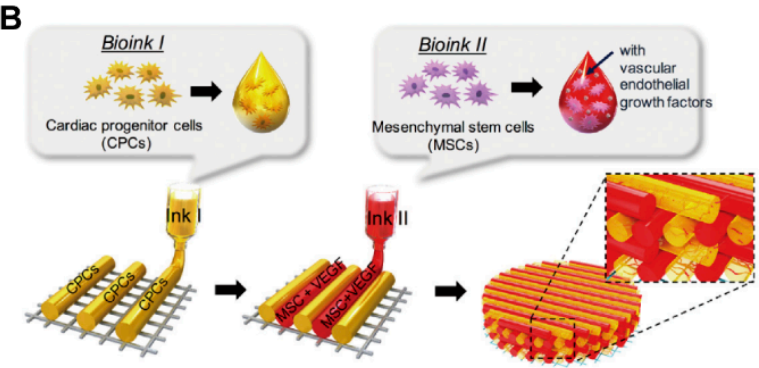

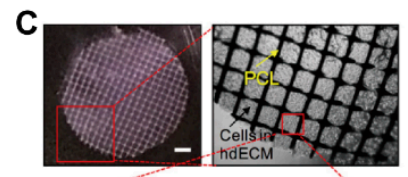

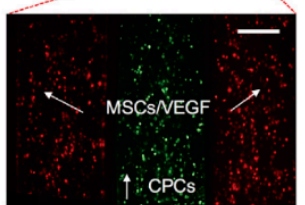

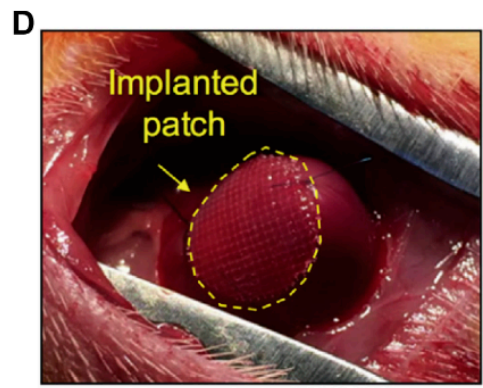

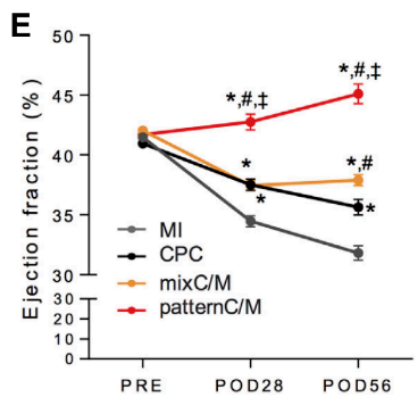

Figure 16. Schematic illustration of 3D cell printing system (A), pre-vascularized stem cell patch including cell-laden bioinks and PCL polymer (B). Representative images of fabricated patch (C) and implanted patch on the epicardium of rat myocardial infraction (MI) model (D). (E) Ejection fraction values after four and eight weeks ( ${ }^{*} p<0.05$ compared with MI; \# $p<0.05$ compared with CPC; $\ddagger p<0.05$ compared with mixC/M). Scale bar: $1 \mathrm{~mm}$ for left top of (C) and $200 \mu \mathrm{m}$ for bottom of (C). Reprinted from [115]. Copyright (2016) Elsevier.

\subsubsection{Other Scaffold Systems}

The goal of cardiac tissue engineering is not only to imitate human heart tissue to reveal physiological mechanisms and disease modeling in vitro, but also to regenerate damaged tissue in vivo. The biggest problem with the in vivo application of cardiac scaffolds is arrhythmia [121]. To overcome this hurdle, the advancement of scaffold fabrication and conductive materials has been investigated. Carbon nanotubes are an example of electrically conductive materials for scaffold formation as a result of their nanoscale size and high conductivity [122]. In a scaffold prepared by mixing carbon nanotubes with a natural material, a gelatin-chitosan hydrogel, the carbon nanotube acts as an electrical nanobridge between myocardial cells, enhancing electrical coupling and inducing synchronous beats [123]. Furthermore, these engineered tissues exhibited conduction rates similar to those of natural myocardial tissue, showing potential for cardiac regeneration.

Similarly, carbon nanofibers have been used in cardiac tissue engineering [124]. Chitosan-carbon composite scaffolds showed higher porosity and elastic modulus values, similar to rat myocardium, and increased electrical properties compared to chitosan-only scaffolds [125]. In addition, culture of neonatal rat heart cells for 14 days yielded an increased metabolic activity, which suggests that the incorporation of carbon fibers not only increases cardiac-specific gene expression, but also intensifies contraction and electrical coupling. In another study, high conductivity and modulus composite hydrogel was developed using a synthetic material, i.e., polyvinyl alcohol (PVA) with carbon fibers (CFs) [126]. The conductivity and elastic modulus of PVA/CFs were similar to those of natural heart tissue, and it was confirmed that the expression of maturation markers, such as $\alpha$-actinin, troponin $\mathrm{T}$, and connexin-43, was increased in the culture of neonatal rat cardiomyocytes. Besides, it is interesting to note that signaling pathways such as $\alpha 5$ and $\beta 1$ integrin-dependent ILK (integrin-linked kinase)/p-AKT (phosphorylated protein kinase B), RhoA (ras homolog family member A), and hypoxia-inducible factor- $1 \alpha$ are activated. When exposed to drugs such as doxorubicin and isoprenaline, PVA/CF has a faster contractile response than hydrogels made with PVA. Thus, scaffolds containing highly conductive 
materials such as carbon nanotubes and carbon fibers can help the maturation and simultaneous beating of myocardial cells and reduce arrhythmias that occur during in vivo implantation of engineered cardiac tissues.

In addition, nanofibers prepared by ECM-like materials including fibrinogen, gelatin, and chitosan were utilized to enhance cell adhesion and migration $[127,128]$. The main motivation of this studies originated from the structural similarity of nanofiber-based scaffold to the fibrous architecture of native ECM. The most common method to construct the nanofibers is electrospinning of the materials onto 2D surface, where cardiomyocytes and other cells are placed for the maturation [129]. Herein, a number of polymers and biological molecules were incorporated to form highly functional nanofibers, resulting in maturation of cardiac tissues [130].

\section{Conclusions}

The advancement of biologically inspired materials opens a new avenue for cardiac tissue engineering by utilizing hPSC-derived cardiomyocytes. The development of cardiac-like tissue for disease modeling is an example of how hPSC-derived cardiomyocytes and novel biomaterials are utilized. To date, many strategies have been explored to closely simulate a native heart, which includes the maturation of hPSC-derived cardiomyocytes, the development of ECM-like biomaterials, and the fabrication and application of cardiac tissues or organoids (Table 1).

Table 1. Natural and synthetic biomaterials for cardiac tissue engineering.

\begin{tabular}{|c|c|c|c|c|}
\hline Source & Scaffold & Type & Advantage & Reference \\
\hline Natural & Fibronectin & 2D surface coating & $\begin{array}{l}\text {-Improved cell attachment, } \\
\text { actin filaments development } \\
\text { and cell stiffness }\end{array}$ & {$[75,76]$} \\
\hline Natural & Fibroblast-derived ECM & 2D surface coating & $\begin{array}{l}\text {-Improved cell adhesion, } \\
\text { cytoskeleton development and } \\
\text { contractility }\end{array}$ & [77] \\
\hline Natural & Decellularized ECM & 2D surface coating & $\begin{array}{l}\text {-Improved cardiac cell } \\
\text { differentiation }\end{array}$ & [78] \\
\hline Synthetic & Peptide-acrylate surface (PAS) & 2D surface coating & $\begin{array}{l}\text {-Chemically defined and } \\
\text { xeno-free materials }\end{array}$ & {$[80]$} \\
\hline Synthetic & $\begin{array}{l}\text { PLA with poly(poly(ethylene } \\
\text { glycol) methacrylate) and } \\
\text { poly[N-(3-aminopropyl) } \\
\text { methacrylamide] }\end{array}$ & 2D surface coating & $\begin{array}{l}\text {-Increased cell attachment and } \\
\text { contractility }\end{array}$ & [81] \\
\hline Synthetic/Natural & $\begin{array}{l}\text { poly(ethylene glycol) } \\
\text { diacrylate with } \\
\text { thiolated-hyaluronic acid (HA) }\end{array}$ & 2D surface coating & $\begin{array}{l}\text {-Increased stiffness of } \\
\text { hydrogels and cell maturation }\end{array}$ & [14] \\
\hline Synthetic/Natural & $\begin{array}{c}\text { Conductive polypyrrole (PPY) } \\
\text { with chitosan }(\mathrm{CHI})\end{array}$ & 2D surface coating & $\begin{array}{l}\text {-Increased } \mathrm{Ca}^{2+} \text { transient and } \\
\text { contractility }\end{array}$ & {$[82]$} \\
\hline Synthetic & PEG with RGD peptide & Surface patterning & $\begin{array}{l}\text {-Improved cell organization } \\
\text { and structural development }\end{array}$ & {$[84,85]$} \\
\hline Synthetic/Natural & $\begin{array}{l}\text { poly(ethylene glycol) with } \\
\text { Matrigel and fibronectin }\end{array}$ & Surface patterning & -Improved cell alignment & [86] \\
\hline Synthetic & $\begin{array}{l}\text { Electrically conductive silicon } \\
\text { nanowires (e-SiNW) }\end{array}$ & Spheroids & $\begin{array}{l}\text {-Improved synchronized } \\
\text { beating and structural } \\
\text { maturation }\end{array}$ & {$[93,94]$} \\
\hline Natural & Fibrin gel & Patterned patch & $\begin{array}{l}\text {-Improved sarcomere } \\
\text { development, maturation, } \\
\text { and synchronization }\end{array}$ & [97] \\
\hline Natural & Collagen type I & Patterned patch & $\begin{array}{l}\text {-Improved synchronized } \\
\text { beating and maturation }\end{array}$ & {$[9,98]$} \\
\hline Natural & Atelocollagen & Fibrous patch & -Improved biocompatibility & [99] \\
\hline Synthetic/Natural & $\begin{array}{l}\text { PCL in gelatin-chitosan } \\
\text { hydrogel }\end{array}$ & Patch & $\begin{array}{l}\text {-Improved mechanical } \\
\text { properties }\end{array}$ & {$[100]$} \\
\hline
\end{tabular}


Table 1. Cont.

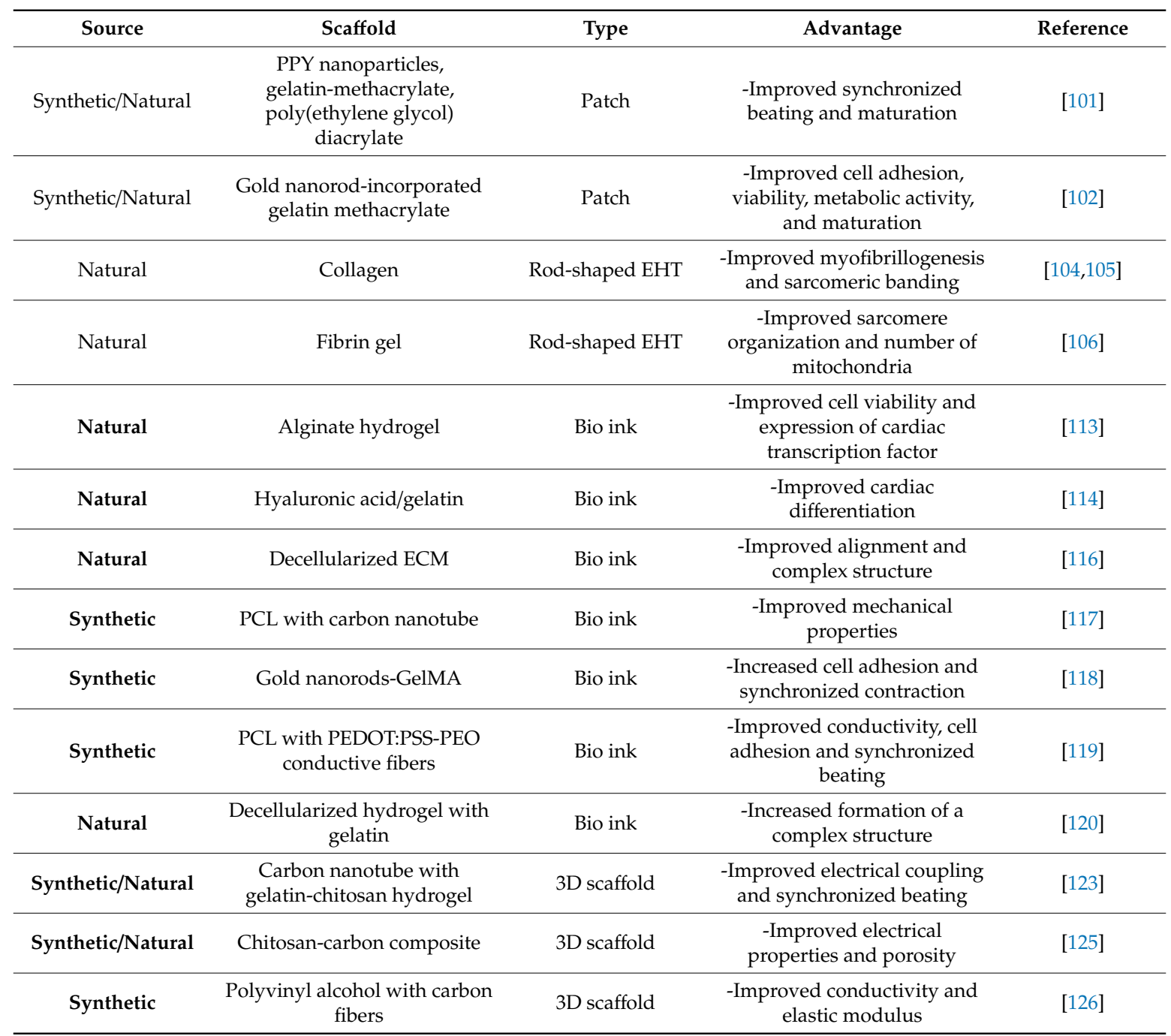

In this review, biomaterials are divided into two types: those of natural and synthetic materials. Each has its pros and cons in terms of the fabrication of cardiac tissues and organoids. For instance, natural materials demonstrate a weak mechanical strength, advocating the application of synthetic materials to enhance tunability and mechanical strength. Thus, the development of a novel biomaterial, such as stimuli-responsive materials, highly tunable materials, and biocompatible materials, would be necessary to advance biomaterial use in cardiac tissue engineering. In addition, combining two types of materials could be an alternative approach, not only in terms of profiting from their strengths, but also to diminish the weaknesses. For the future development, spatial and temporal (four-dimensional, 4D) regulation of microenvironment by biomaterials would be necessitated to commence the next generation of tissue engineering, which allows for the smart responding to different states of biological pathways during the regeneration of damaged tissues. Although, herein, we introduce the current state of biomaterials in cardiac tissue engineering, we are unable to address all the seminal works.

In addition to biomaterials, a number of fabrication methods to achieve maturated myocardial tissue are explained. Spheroid is introduced as one of the simplest 3D platforms composed of cells, which is often co-assembled with biomaterials to improve spheroids in biological functions. Cardiac patches are described for their use in myocardial regeneration through in vivo transplantation, which is prepared using various patterns, cells, and biomaterials. Rod-shaped EHT is explained as an example of a 3D in vitro cardiac tissue that most closely mimics the aligned myocardial tissue of the heart. $3 \mathrm{D}$ bioprinting is an emerging technology to manufacture thick cardiac tissues while controlling 
biomaterials, cell types, and patterns. A number of studies on these multidisciplinary approaches are ongoing and the data are accumulating. Future progress in biomaterials and strategies for their application in cardiac engineering will enhance our understanding of cardiac development, maturation, and regeneration.

Author Contributions: Conceptualization, J.K. and Y.P.; investigation, Y.J.; writing—original draft preparation, Y.J.; writing - review and editing, J.K. and Y.P.; supervision, J.K. and Y.P.; project administration, J.K. and Y.P. All authors have read and agreed to the published version of the manuscript.

Funding: This research was funded by the National Research Foundation of Korea, Republic of Korea, grant No. 2016-M3A9B6947892 and a Korea University Grant.

Conflicts of Interest: The authors declare no conflict of interest.

\section{References}

1. Swinehart, I.T.; Badylak, S.F. Extracellular matrix bioscaffolds in tissue remodeling and morphogenesis. Dev. Dyn 2016, 245, 351-360. [CrossRef] [PubMed]

2. Lu, P.; Takai, K.; Weaver, V.M.; Werb, Z. Extracellular matrix degradation and remodeling in development and disease. Cold Spring Harb. Perspect. Biol. 2011, 3. [CrossRef] [PubMed]

3. Chin, I.L.; Hool, L.; Choi, Y.S. A Review of in vitro Platforms for Understanding Cardiomyocyte Mechanobiology. Front. Bioeng. Biotechnol. 2019, 7, 133. [CrossRef] [PubMed]

4. Williams, C.; Quinn, K.P.; Georgakoudi, I.; Black, L.D., 3rd. Young developmental age cardiac extracellular matrix promotes the expansion of neonatal cardiomyocytes in vitro. Acta Biomater. 2014, 10, 194-204. [CrossRef] [PubMed]

5. Pinto, A.R.; Ilinykh, A.; Ivey, M.J.; Kuwabara, J.T.; D'Antoni, M.L.; Debuque, R.; Chandran, A.; Wang, L.; Arora, K.; Rosenthal, N.A.; et al. Revisiting Cardiac Cellular Composition. Circ. Res. 2016, 118, 400-409. [CrossRef]

6. Wagner, J.U.G.; Pham, M.D.; Nicin, L.; Hammer, M.; Bottermann, K.; Yuan, T.; Sharma, R.; John, D.; Muhly-Reinholz, M.; Tombor, L.; et al. Dissection of heterocellular cross-talk in vascularized cardiac tissue mimetics. J. Mol. Cell. Cardiol. 2020, 138, 269-282. [CrossRef]

7. Ronaldson-Bouchard, K.; Ma, S.P.; Yeager, K.; Chen, T.; Song, L.; Sirabella, D.; Morikawa, K.; Teles, D.; Yazawa, M.; Vunjak-Novakovic, G. Advanced maturation of human cardiac tissue grown from pluripotent stem cells. Nature 2018, 556, 239-243. [CrossRef]

8. van Meer, B.J.; Tertoolen, L.G.; Mummery, C.L. Concise Review: Measuring Physiological Responses of Human Pluripotent Stem Cell Derived Cardiomyocytes to Drugs and Disease. Stem Cells 2016, 34, 2008-2015. [CrossRef]

9. Jang, Y.; Jung, D.J.; Choi, S.-C.; Lim, D.-S.; Kim, J.-H.; Jeoung, G.S.; Kim, J.; Park, Y. Multidimensional assembly using layer-by-layer deposition for synchronized cardiac macro tissues. RSC Adv. 2020, 10, 18806-18815. [CrossRef]

10. Humphrey, J.D.; Dufresne, E.R.; Schwartz, M.A. Mechanotransduction and extracellular matrix homeostasis. Nat. Rev. Mol. Cell Biol. 2014, 15, 802-812. [CrossRef]

11. Young, J.L.; Kretchmer, K.; Ondeck, M.G.; Zambon, A.C.; Engler, A.J. Mechanosensitive kinases regulate stiffness-induced cardiomyocyte maturation. Sci. Rep. 2014, 4, 6425. [CrossRef] [PubMed]

12. Yoshida, S.; Miyagawa, S.; Fukushima, S.; Kawamura, T.; Kashiyama, N.; Ohashi, F.; Toyofuku, T.; Toda, K.; Sawa, Y. Maturation of Human Induced Pluripotent Stem Cell-Derived Cardiomyocytes by Soluble Factors from Human Mesenchymal Stem Cells. Mol. Ther. 2018, 26, 2681-2695. [CrossRef] [PubMed]

13. Aamodt, J.M.; Grainger, D.W. Extracellular matrix-based biomaterial scaffolds and the host response. Biomaterials 2016, 86, 68-82. [CrossRef] [PubMed]

14. Young, J.L.; Engler, A.J. Hydrogels with time-dependent material properties enhance cardiomyocyte differentiation in vitro. Biomaterials 2011, 32, 1002-1009. [CrossRef] [PubMed]

15. Lutolf, M.P.; Hubbell, J.A. Synthetic biomaterials as instructive extracellular microenvironments for morphogenesis in tissue engineering. Nat. Biotechnol. 2005, 23, 47-55. [CrossRef] [PubMed] 
16. Kapalczynska, M.; Kolenda, T.; Przybyla, W.; Zajaczkowska, M.; Teresiak, A.; Filas, V.; Ibbs, M.; Blizniak, R.; Luczewski, L.; Lamperska, K. 2D and 3D cell cultures-A comparison of different types of cancer cell cultures. Arch. Med. Sci. 2018, 14, 910-919. [CrossRef]

17. Kamei, K.I.; Koyama, Y.; Tokunaga, Y.; Mashimo, Y.; Yoshioka, M.; Fockenberg, C.; Mosbergen, R.; Korn, O.; Wells, C.; Chen, Y. Characterization of Phenotypic and Transcriptional Differences in Human Pluripotent Stem Cells under 2D and 3D Culture Conditions. Adv. Healthc. Mater. 2016, 5, 2951-2958. [CrossRef]

18. Beauchamp, P.; Jackson, C.B.; Ozhathil, L.C.; Agarkova, I.; Galindo, C.L.; Sawyer, D.B.; Suter, T.M.; Zuppinger, C. 3D Co-culture of hiPSC-Derived Cardiomyocytes with Cardiac Fibroblasts Improves Tissue-Like Features of Cardiac Spheroids. Front. Mol. Biosci. 2020, 7, 14. [CrossRef]

19. Eder, A.; Vollert, I.; Hansen, A.; Eschenhagen, T. Human engineered heart tissue as a model system for drug testing. Adv. Drug Deliv. Rev. 2016, 96, 214-224. [CrossRef]

20. Paolo Capparè, G.T.; Sberna, M.T.; Panina-Bordignon, P. The emerging role of stem cells in regenerative dentistry. Curr. Gene Ther. 2020, 20. [CrossRef]

21. Tete, G.; Cappare, P.; Gherlone, E. New Application of Osteogenic Differentiation from HiPS Stem Cells for Evaluating the Osteogenic Potential of Nanomaterials in Dentistry. Int. J. Environ. Res. Public Health 2020, 17, 1947. [CrossRef] [PubMed]

22. Rosales, A.M.; Anseth, K.S. The design of reversible hydrogels to capture extracellular matrix dynamics. Nat. Rev. Mater. 2016, 1. [CrossRef] [PubMed]

23. Aszodi, A.; Legate, K.R.; Nakchbandi, I.; Fassler, R. What mouse mutants teach us about extracellular matrix function. Annu. Rev. Cell Dev. Biol. 2006, 22, 591-621. [CrossRef] [PubMed]

24. Ricard-Blum, S. The collagen family. Cold Spring Harb. Perspect. Biol. 2011, 3, a004978. [CrossRef]

25. Sorushanova, A.; Delgado, L.M.; Wu, Z.; Shologu, N.; Kshirsagar, A.; Raghunath, R.; Mullen, A.M.; Bayon, Y.; Pandit, A.; Raghunath, M.; et al. The Collagen Suprafamily: From Biosynthesis to Advanced Biomaterial Development. Adv. Mater. 2019, 31, e1801651. [CrossRef]

26. Chevallay, B.; Herbage, D. Collagen-based biomaterials as $3 \mathrm{D}$ scaffold for cell cultures_applications for tissue engineering and gene therapy. Med Biol. Eng. Comput. 2000, 38, 211-218. [CrossRef]

27. Ben Shoham, A.; Rot, C.; Stern, T.; Krief, S.; Akiva, A.; Dadosh, T.; Sabany, H.; Lu, Y.; Kadler, K.E.; Zelzer, E. Deposition of collagen type I onto skeletal endothelium reveals a new role for blood vessels in regulating bone morphology. Development 2016, 143, 3933-3943. [CrossRef]

28. Sun, J.L.; Jiao, K.; Niu, L.N.; Jiao, Y.; Song, Q.; Shen, L.J.; Tay, F.R.; Chen, J.H. Intrafibrillar silicified collagen scaffold modulates monocyte to promote cell homing, angiogenesis and bone regeneration. Biomaterials 2017, 113, 203-216. [CrossRef]

29. Rhee, S.; Puetzer, J.L.; Mason, B.N.; Reinhart-King, C.A.; Bonassar, L.J. 3D Bioprinting of Spatially Heterogeneous Collagen Constructs for Cartilage Tissue Engineering. ACS Biomater. Sci. Eng. 2016, 2, 1800-1805. [CrossRef]

30. Meng, Q.; An, S.; Damion, R.A.; Jin, Z.; Wilcox, R.; Fisher, J.; Jones, A. The effect of collagen fibril orientation on the biphasic mechanics of articular cartilage. J. Mech. Behav. Biomed. Mater. 2017, 65, 439-453. [CrossRef]

31. Sawadkar, P.; Sibbons, P.; Ahmed, T.; Bozec, L.; Mudera, V. Engineering of a Functional Tendon Using Collagen As a Natural Polymer. ACS Biomater. Sci. Eng. 2019, 5, 5218-5228. [CrossRef]

32. Yang, S.; Shi, X.; Li, X.; Wang, J.; Wang, Y.; Luo, Y. Oriented collagen fiber membranes formed through counter-rotating extrusion and their application in tendon regeneration. Biomaterials 2019, 207, 61-75. [CrossRef] [PubMed]

33. McCoy, M.G.; Wei, J.M.; Choi, S.; Goerger, J.P.; Zipfel, W.; Fischbach, C. Collagen Fiber Orientation Regulates 3D Vascular Network Formation and Alignment. ACS Biomater. Sci. Eng. 2018, 4, 2967-2976. [CrossRef]

34. Sherman, V.R.; Tang, Y.; Zhao, S.; Yang, W.; Meyers, M.A. Structural characterization and viscoelastic constitutive modeling of skin. Acta Biomater. 2017, 53, 460-469. [CrossRef]

35. Lee, A.; Hudson, A.R.; Shiwarski, D.J.; Tashman, J.W.; Hinton, T.J.; Yerneni, S.; Bliley, J.M.; Campbell, P.G.; Feinberg, A.W. 3D bioprinting of collagen to rebuild components of the human heart. Science 2019, 365, 482-487. [CrossRef]

36. Bozkurt, A.; Boecker, A.; Tank, J.; Altinova, H.; Deumens, R.; Dabhi, C.; Tolba, R.; Weis, J.; Brook, G.A.; Pallua, N.; et al. Efficient bridging of $20 \mathrm{~mm}$ rat sciatic nerve lesions with a longitudinally micro-structured collagen scaffold. Biomaterials 2016, 75, 112-122. [CrossRef] 
37. Saeki, M.; Tanaka, K.; Imatani, J.; Okamoto, H.; Watanabe, K.; Nakamura, T.; Gotani, H.; Ohi, H.; Nakamura, R.; Hirata, H. Efficacy and safety of novel collagen conduits filled with collagen filaments to treat patients with peripheral nerve injury: A multicenter, controlled, open-label clinical trial. Injury 2018, 49, 766-774. [CrossRef] [PubMed]

38. Matthews, J.A.; Wnek, G.E.; Simpson, D.G.; Bowlin, G.L. Electrospinning of collagen nanofibers. Biomacromolecules 2002, 3, 232-238. [CrossRef]

39. Yang, W.; Meyers, M.A.; Ritchie, R.O. Structural architectures with toughening mechanisms in Nature: A review of the materials science of Type-I collagenous materials. Prog. Mater. Sci. 2019, 103, 425-483. [CrossRef]

40. Buehler, M.J. Nature designs tough collagen: Explaining the nanostructure of collagen fibrils. Proc. Natl. Acad. Sci. USA 2006, 103, 12285-12290. [CrossRef]

41. Wolf, K.; Alexander, S.; Schacht, V.; Coussens, L.M.; von Andrian, U.H.; van Rheenen, J.; Deryugina, E.; Friedl, P. Collagen-based cell migration models in vitro and in vivo. Semin. Cell Dev. Biol. 2009, 20, 931-941. [CrossRef] [PubMed]

42. Dong, C.; Lv, Y. Application of Collagen Scaffold in Tissue Engineering: Recent Advances and New Perspectives. Polymers 2016, 8, 42. [CrossRef] [PubMed]

43. Chiti, M.C.; Dolmans, M.M.; Donnez, J.; Amorim, C.A. Fibrin in Reproductive Tissue Engineering: A Review on Its Application as a Biomaterial for Fertility Preservation. Ann. Biomed. Eng. 2017, 45, 1650-1663. [CrossRef] [PubMed]

44. Mosesson, M.W. Fibrinogen and fibrin structure and functions. J. Thromb. Haemost. 2005, 3, $1894-1904$. [CrossRef] [PubMed]

45. Zhao, H.; Ma, L.; Zhou, J.; Mao, Z.; Gao, C.; Shen, J. Fabrication and physical and biological properties of fibrin gel derived from human plasma. Biomed. Mater. 2008, 3, 015001. [CrossRef]

46. Zollinger, A.J.; Smith, M.L. Fibronectin, the extracellular glue. Matrix Biol. 2017, 60, 27-37. [CrossRef]

47. Singh, P.; Carraher, C.; Schwarzbauer, J.E. Assembly of fibronectin extracellular matrix. Annu. Rev. Cell Dev. Biol. 2010, 26, 397-419. [CrossRef]

48. Mao, Y.; Schwarzbauer, J.E. Fibronectin fibrillogenesis, a cell-mediated matrix assembly process. Matrix Biol. 2005, 24, 389-399. [CrossRef]

49. Shahbazi, M.N.; Scialdone, A.; Skorupska, N.; Weberling, A.; Recher, G.; Zhu, M.; Jedrusik, A.; Devito, L.G.; Noli, L.; Macaulay, I.C.; et al. Pluripotent state transitions coordinate morphogenesis in mouse and human embryos. Nature 2017, 552, 239-243. [CrossRef]

50. Uemura, M.; Refaat, M.M.; Shinoyama, M.; Hayashi, H.; Hashimoto, N.; Takahashi, J. Matrigel supports survival and neuronal differentiation of grafted embryonic stem cell-derived neural precursor cells. J. Neurosci. Res. 2010, 88, 542-551. [CrossRef]

51. Wang, J.; Chu, R.; Ni, N.; Nan, G. The effect of Matrigel as scaffold material for neural stem cell transplantation for treating spinal cord injury. Sci. Rep. 2020, 10, 2576. [CrossRef] [PubMed]

52. Benton, G.; Kleinman, H.K.; George, J.; Arnaoutova, I. Multiple uses of basement membrane-like matrix (BME/Matrigel) in vitro and in vivo with cancer cells. Int. J. Cancer 2011, 128, 1751-1757. [CrossRef] [PubMed]

53. Fridman, R.; Benton, G.; Aranoutova, I.; Kleinman, H.K.; Bonfil, R.D. Increased initiation and growth of tumor cell lines, cancer stem cells and biopsy material in mice using basement membrane matrix protein (Cultrex or Matrigel) co-injection. Nat. Protoc. 2012, 7, 1138-1144. [CrossRef] [PubMed]

54. Xu, C.; Inokuma, M.S.; Denham, J.; Golds, K.; Kundu, P.; Gold, J.D.; Carpenter, M.K. Feeder-free growth of undifferentiated human embryonic stem cells. Nat. Biotechnol. 2001, 19, 971-974. [CrossRef] [PubMed]

55. Hughes, C.S.; Postovit, L.M.; Lajoie, G.A. Matrigel: A complex protein mixture required for optimal growth of cell culture. Proteomics 2010, 10, 1886-1890. [CrossRef]

56. Benton, G.; Arnaoutova, I.; George, J.; Kleinman, H.K.; Koblinski, J. Matrigel: From discovery and ECM mimicry to assays and models for cancer research. Adv. Drug Deliv. Rev. 2014, 79, 3-18. [CrossRef]

57. Fischbach, C.; Chen, R.; Matsumoto, T.; Schmelzle, T.; Brugge, J.S.; Polverini, P.J.; Mooney, D.J. Engineering tumors with 3D scaffolds. Nat. Methods 2007, 4, 855-860. [CrossRef]

58. Poincloux, R.; Collin, O.; Lizarraga, F.; Romao, M.; Debray, M.; Piel, M.; Chavrier, P. Contractility of the cell rear drives invasion of breast tumor cells in 3D Matrigel. Proc. Natl. Acad. Sci. USA 2011, 108, 1943-1948. [CrossRef] 
59. Sieveking, D.P.; Buckle, A.; Celermajer, D.S.; Ng, M.K. Strikingly different angiogenic properties of endothelial progenitor cell subpopulations: Insights from a novel human angiogenesis assay. J. Am. Coll. Cardiol. 2008, 51, 660-668. [CrossRef]

60. Mousseau, Y.; Mollard, S.; Qiu, H.; Richard, L.; Cazal, R.; Nizou, A.; Vedrenne, N.; Remi, S.; Baaj, Y.; Fourcade, L.; et al. In vitro 3D angiogenesis assay in egg white matrix: Comparison to Matrigel, compatibility to various species, and suitability for drug testing. Lab. Investig. 2014, 94, 340-349. [CrossRef]

61. Gilbert, T.W.; Sellaro, T.L.; Badylak, S.F. Decellularization of tissues and organs. Biomaterials 2006, 27, 3675-3683. [CrossRef] [PubMed]

62. Song, J.J.; Ott, H.C. Organ engineering based on decellularized matrix scaffolds. Trends Mol. Med. 2011, 17, 424-432. [CrossRef] [PubMed]

63. Hoshiba, T.; Lu, H.; Kawazoe, N.; Chen, G. Decellularized matrices for tissue engineering. Expert Opin. Biol. Ther. 2010, 10, 1717-1728. [CrossRef] [PubMed]

64. Crapo, P.M.; Gilbert, T.W.; Badylak, S.F. An overview of tissue and whole organ decellularization processes. Biomaterials 2011, 32, 3233-3243. [CrossRef] [PubMed]

65. Place, E.S.; George, J.H.; Williams, C.K.; Stevens, M.M. Synthetic polymer scaffolds for tissue engineering. Chem. Soc. Rev. 2009, 38, 1139-1151. [CrossRef] [PubMed]

66. Abedalwafa, M.; Wang, F.; Wang, L.; Li, C. Biodegradable poly-epsilon-caprolactone (PCL) for tissue engineering applications: A review. Rev. Adv. Mater. Sci. 2013, 34, 123-140.

67. Labet, M.; Thielemans, W. Synthesis of polycaprolactone: A review. Chem. Soc. Rev. 2009, 38, 3484-3504. [CrossRef]

68. Shah Mohammadi, M.; Bureau, M.N.; Nazhat, S.N. Polylactic acid (PLA) biomedical foams for tissue engineering. In Biomedical Foams for Tissue Engineering Applications; Woodhead Publishing: Cambridge, UK, 2014; pp. 313-334. [CrossRef]

69. Farah, S.; Anderson, D.G.; Langer, R. Physical and mechanical properties of PLA, and their functions in widespread applications-A comprehensive review. Adv. Drug Deliv. Rev. 2016, 107, 367-392. [CrossRef]

70. Fan, X.; Wang, M.; Yuan, D.; He, C. Amphiphilic conetworks and gels physically cross-linked via stereocomplexation of polylactide. Langmuir 2013, 29, 14307-14313. [CrossRef]

71. Wolf, M.T.; Dearth, C.L.; Sonnenberg, S.B.; Loboa, E.G.; Badylak, S.F. Naturally derived and synthetic scaffolds for skeletal muscle reconstruction. Adv. Drug Deliv. Rev. 2015, 84, 208-221. [CrossRef]

72. Lin, C.C.; Anseth, K.S. PEG hydrogels for the controlled release of biomolecules in regenerative medicine. Pharm. Res. 2009, 26, 631-643. [CrossRef] [PubMed]

73. Veronese, F.M.; Pasut, G. PEGylation, successful approach to drug delivery. Drug Discov. Today 2005, 10, 1451-1458. [CrossRef]

74. Reid, B.; Gibson, M.; Singh, A.; Taube, J.; Furlong, C.; Murcia, M.; Elisseeff, J. PEG hydrogel degradation and the role of the surrounding tissue environment. J. Tissue Eng. Regen. Med. 2015, 9, 315-318. [CrossRef] [PubMed]

75. Wu, X.; Sun, Z.; Foskett, A.; Trzeciakowski, J.P.; Meininger, G.A.; Muthuchamy, M. Cardiomyocyte contractile status is associated with differences in fibronectin and integrin interactions. Am. J. Physiol. Heart Circ. Physiol. 2010, 298, H2071-H2081. [CrossRef]

76. Deitch, S.; Gao, B.Z.; Dean, D. Effect of matrix on cardiomyocyte viscoelastic properties in 2D culture. Mol. Cell. Biomech. 2012, 9, 227-249. [PubMed]

77. Vanwinkle, W.B.; Snuggs, M.B.; Buja, L.M. Cardiogel: A biosynthetic extracellular matrix for cardiomyocyte culture. In Vitro Cell. Dev. Biol. 1996, 32, 478-485. [CrossRef]

78. Baghalishahi, M.; Efthekhar-Vaghefi, S.H.; Piryaei, A.; Nematolahi-Mahani, S.N.; Mollaei, H.R.; Sadeghi, Y. Cardiac extracellular matrix hydrogel together with or without inducer cocktail improves human adipose tissue-derived stem cells differentiation into cardiomyocyte-like cells. Biochem. Biophys. Res. Commun. 2018, 502, 215-225. [CrossRef]

79. Kleinman, H.K.; Martin, G.R. Matrigel: Basement membrane matrix with biological activity. Semin. Cancer Biol. 2005, 15, 378-386. [CrossRef]

80. Melkoumian, Z.; Weber, J.L.; Weber, D.M.; Fadeev, A.G.; Zhou, Y.; Dolley-Sonneville, P.; Yang, J.; Qiu, L.; Priest, C.A.; Shogbon, C.; et al. Synthetic peptide-acrylate surfaces for long-term self-renewal and cardiomyocyte differentiation of human embryonic stem cells. Nat. Biotechnol. 2010, 28, 606-610. [CrossRef] 
81. Alvarez-Paino, M.; Amer, M.H.; Nasir, A.; Cuzzucoli Crucitti, V.; Thorpe, J.; Burroughs, L.; Needham, D.; Denning, C.; Alexander, M.R.; Alexander, C.; et al. Polymer Microparticles with Defined Surface Chemistry and Topography Mediate the Formation of Stem Cell Aggregates and Cardiomyocyte Function. ACS Appl. Mater. Interfaces 2019, 11, 34560-34574. [CrossRef]

82. Cui, Z.; Ni, N.C.; Wu, J.; Du, G.Q.; He, S.; Yau, T.M.; Weisel, R.D.; Sung, H.W.; Li, R.K. Polypyrrole-chitosan conductive biomaterial synchronizes cardiomyocyte contraction and improves myocardial electrical impulse propagation. Theranostics 2018, 8, 2752-2764. [CrossRef] [PubMed]

83. Nakane, T.; Masumoto, H.; Tinney, J.P.; Yuan, F.; Kowalski, W.J.; Ye, F.; LeBlanc, A.J.; Sakata, R.; Yamashita, J.K.; Keller, B.B. Impact of Cell Composition and Geometry on Human Induced Pluripotent Stem Cells-Derived Engineered Cardiac Tissue. Sci. Rep. 2017, 7, 45641. [CrossRef] [PubMed]

84. Kim, D.H.; Kim, P.; Song, I.; Cha, J.M.; Lee, S.H.; Kim, B.; Suh, K.Y. Guided three-dimensional growth of functional cardiomyocytes on polyethylene glycol nanostructure. Langmuir 2006, 22, 5419-5426. [CrossRef]

85. Carson, D.; Hnilova, M.; Yang, X.; Nemeth, C.L.; Tsui, J.H.; Smith, A.S.; Jiao, A.; Regnier, M.; Murry, C.E.; Tamerler, C.; et al. Nanotopography-Induced Structural Anisotropy and Sarcomere Development in Human Cardiomyocytes Derived from Induced Pluripotent Stem Cells. ACS Appl. Mater. Interfaces 2016, 8, 21923-21932. [CrossRef]

86. Salick, M.R.; Napiwocki, B.N.; Sha, J.; Knight, G.T.; Chindhy, S.A.; Kamp, T.J.; Ashton, R.S.; Crone, W.C. Micropattern width dependent sarcomere development in human ESC-derived cardiomyocytes. Biomaterials 2014, 35, 4454-4464. [CrossRef]

87. Abadi, P.P.; Garbern, J.C.; Behzadi, S.; Hill, M.J.; Tresback, J.S.; Heydari, T.; Ejtehadi, M.R.; Ahmed, N.; Copley, E.; Aghaverdi, H.; et al. Engineering of Mature Human Induced Pluripotent Stem Cell-Derived Cardiomyocytes Using Substrates with Multiscale Topography. Adv. Funct. Mater. 2018, 28. [CrossRef]

88. Xu, B.; Magli, A.; Anugrah, Y.; Koester, S.J.; Perlingeiro, R.C.R.; Shen, W. Nanotopography-responsive myotube alignment and orientation as a sensitive phenotypic biomarker for Duchenne Muscular Dystrophy. Biomaterials 2018, 183, 54-66. [CrossRef]

89. Achilli, T.M.; Meyer, J.; Morgan, J.R. Advances in the formation, use and understanding of multi-cellular spheroids. Expert Opin. Biol. Ther. 2012, 12, 1347-1360. [CrossRef]

90. Pontes Soares, C.; Midlej, V.; de Oliveira, M.E.; Benchimol, M.; Costa, M.L.; Mermelstein, C. 2D and 3D-organized cardiac cells shows differences in cellular morphology, adhesion junctions, presence of myofibrils and protein expression. PLoS ONE 2012, 7, e38147. [CrossRef]

91. Zuppinger, C. 3D culture for cardiac cells. Biochim. Biophys. Acta 2016, 1863, 1873-1881. [CrossRef]

92. Polonchuk, L.; Chabria, M.; Badi, L.; Hoflack, J.C.; Figtree, G.; Davies, M.J.; Gentile, C. Cardiac spheroids as promising in vitro models to study the human heart microenvironment. Sci. Rep. 2017, 7, 7005. [CrossRef] [PubMed]

93. Tan, Y.; Richards, D.; Xu, R.; Stewart-Clark, S.; Mani, S.K.; Borg, T.K.; Menick, D.R.; Tian, B.; Mei, Y. Silicon nanowire-induced maturation of cardiomyocytes derived from human induced pluripotent stem cells. Nano Lett. 2015, 15, 2765-2772. [CrossRef] [PubMed]

94. Tan, Y.; Richards, D.; Coyle, R.C.; Yao, J.; Xu, R.; Gou, W.; Wang, H.; Menick, D.R.; Tian, B.; Mei, Y. Cell number per spheroid and electrical conductivity of nanowires influence the function of silicon nanowired human cardiac spheroids. Acta Biomater. 2017, 51, 495-504. [CrossRef] [PubMed]

95. Tallawi, M.; Rosellini, E.; Barbani, N.; Cascone, M.G.; Rai, R.; Saint-Pierre, G.; Boccaccini, A.R. Strategies for the chemical and biological functionalization of scaffolds for cardiac tissue engineering: A review. J. R. Soc. Interface 2015, 12, 20150254. [CrossRef] [PubMed]

96. Lakshmanan, R.; Krishnan, U.M.; Sethuraman, S. Living cardiac patch: The elixir for cardiac regeneration. Expert Opin. Biol. Ther. 2012, 12, 1623-1640. [CrossRef]

97. Zhang, D.; Shadrin, I.Y.; Lam, J.; Xian, H.Q.; Snodgrass, H.R.; Bursac, N. Tissue-engineered cardiac patch for advanced functional maturation of human ESC-derived cardiomyocytes. Biomaterials 2013, 34, 5813-5820. [CrossRef]

98. Jang, Y.; Choi, S.C.; Lim, D.S.; Kim, J.H.; Kim, J.; Park, Y. Modulating cardiomyocyte and fibroblast interaction using layer-by-layer deposition facilitates synchronisation of cardiac macro tissues. Soft Matter 2020, 16, 428-434. [CrossRef] 
99. Kitsara, M.; Joanne, P.; Boitard, S.E.; Ben Dhiab, I.; Poinard, B.; Menasché, P.; Gagnieu, C.; Forest, P.; Agbulut, O.; Chen, Y. Fabrication of cardiac patch by using electrospun collagen fibers. Microelectron. Eng. 2015, 144, 46-50. [CrossRef]

100. Pok, S.; Myers, J.D.; Madihally, S.V.; Jacot, J.G. A multilayered scaffold of a chitosan and gelatin hydrogel supported by a PCL core for cardiac tissue engineering. Acta Biomater. 2013, 9, 5630-5642. [CrossRef]

101. Wang, L.; Jiang, J.; Hua, W.; Darabi, A.; Song, X.; Song, C.; Zhong, W.; Xing, M.M.Q.; Qiu, X. Mussel-Inspired Conductive Cryogel as Cardiac Tissue Patch to Repair Myocardial Infarction by Migration of Conductive Nanoparticles. Adv. Funct. Mater. 2016, 26, 4293-4305. [CrossRef]

102. Navaei, A.; Saini, H.; Christenson, W.; Sullivan, R.T.; Ros, R.; Nikkhah, M. Gold nanorod-incorporated gelatin-based conductive hydrogels for engineering cardiac tissue constructs. Acta Biomater. 2016, 41, 133-146. [CrossRef] [PubMed]

103. Hansen, A.; Eder, A.; Bonstrup, M.; Flato, M.; Mewe, M.; Schaaf, S.; Aksehirlioglu, B.; Schwoerer, A.P.; Uebeler, J.; Eschenhagen, T. Development of a drug screening platform based on engineered heart tissue. Circ. Res. 2010, 107, 35-44. [CrossRef] [PubMed]

104. Tulloch, N.L.; Muskheli, V.; Razumova, M.V.; Korte, F.S.; Regnier, M.; Hauch, K.D.; Pabon, L.; Reinecke, H.; Murry, C.E. Growth of engineered human myocardium with mechanical loading and vascular coculture. Circ. Res. 2011, 109, 47-59. [CrossRef] [PubMed]

105. Bargehr, J.; Ong, L.P.; Colzani, M.; Davaapil, H.; Hofsteen, P.; Bhandari, S.; Gambardella, L.; Le Novere, N.; Iyer, D.; Sampaziotis, F.; et al. Epicardial cells derived from human embryonic stem cells augment cardiomyocyte-driven heart regeneration. Nat. Biotechnol. 2019, 37, 895-906. [CrossRef]

106. Mannhardt, I.; Breckwoldt, K.; Letuffe-Breniere, D.; Schaaf, S.; Schulz, H.; Neuber, C.; Benzin, A.; Werner, T.; Eder, A.; Schulze, T.; et al. Human Engineered Heart Tissue: Analysis of Contractile Force. Stem Cell Rep. 2016, 7, 29-42. [CrossRef]

107. Lemme, M.; Ulmer, B.M.; Lemoine, M.D.; Zech, A.T.L.; Flenner, F.; Ravens, U.; Reichenspurner, H.; Rol-Garcia, M.; Smith, G.; Hansen, A.; et al. Atrial-like Engineered Heart Tissue: An in vitro Model of the Human Atrium. Stem Cell Rep. 2018, 11, 1378-1390. [CrossRef]

108. Maffioletti, S.M.; Sarcar, S.; Henderson, A.B.H.; Mannhardt, I.; Pinton, L.; Moyle, L.A.; Steele-Stallard, H.; Cappellari, O.; Wells, K.E.; Ferrari, G.; et al. Three-Dimensional Human iPSC-Derived Artificial Skeletal Muscles Model Muscular Dystrophies and Enable Multilineage Tissue Engineering. Cell Rep. 2018, 23, 899-908. [CrossRef]

109. Cohn, R.; Thakar, K.; Lowe, A.; Ladha, F.A.; Pettinato, A.M.; Romano, R.; Meredith, E.; Chen, Y.S.; Atamanuk, K.; Huey, B.D.; et al. A Contraction Stress Model of Hypertrophic Cardiomyopathy due to Sarcomere Mutations. Stem Cell Rep. 2019, 12, 71-83. [CrossRef]

110. Rodriguez, M.L.; Werner, T.R.; Becker, B.; Eschenhagen, T.; Hirt, M.N. A magnetics-based approach for fine-tuning afterload in engineered heart tissues. ACS Biomater. Sci. Eng. 2019, 5, 3663-3675. [CrossRef]

111. Tijore, A.; Irvine, S.A.; Sarig, U.; Mhaisalkar, P.; Baisane, V.; Venkatraman, S. Contact guidance for cardiac tissue engineering using 3D bioprinted gelatin patterned hydrogel. Biofabrication 2018, 10, 025003. [CrossRef]

112. Lind, J.U.; Busbee, T.A.; Valentine, A.D.; Pasqualini, F.S.; Yuan, H.; Yadid, M.; Park, S.J.; Kotikian, A.; Nesmith, A.P.; Campbell, P.H.; et al. Instrumented cardiac microphysiological devices via multimaterial three-dimensional printing. Nat. Mater. 2017, 16, 303-308. [CrossRef] [PubMed]

113. Gaetani, R.; Doevendans, P.A.; Metz, C.H.; Alblas, J.; Messina, E.; Giacomello, A.; Sluijter, J.P. Cardiac tissue engineering using tissue printing technology and human cardiac progenitor cells. Biomaterials 2012, 33, 1782-1790. [CrossRef] [PubMed]

114. Gaetani, R.; Feyen, D.A.; Verhage, V.; Slaats, R.; Messina, E.; Christman, K.L.; Giacomello, A.; Doevendans, P.A.; Sluijter, J.P. Epicardial application of cardiac progenitor cells in a 3D-printed gelatin/hyaluronic acid patch preserves cardiac function after myocardial infarction. Biomaterials 2015, 61, 339-348. [CrossRef] [PubMed]

115. Jang, J.; Park, H.J.; Kim, S.W.; Kim, H.; Park, J.Y.; Na, S.J.; Kim, H.J.; Park, M.N.; Choi, S.H.; Park, S.H.; et al. 3D printed complex tissue construct using stem cell-laden decellularized extracellular matrix bioinks for cardiac repair. Biomaterials 2017, 112, 264-274. [CrossRef] [PubMed]

116. Wang, Z.; Lee, S.J.; Cheng, H.J.; Yoo, J.J.; Atala, A. 3D bioprinted functional and contractile cardiac tissue constructs. Acta Biomater. 2018, 70, 48-56. [CrossRef]

117. Ho, C.M.; Mishra, A.; Lin, P.T.; Ng, S.H.; Yeong, W.Y.; Kim, Y.J.; Yoon, Y.J. 3D Printed Polycaprolactone Carbon Nanotube Composite Scaffolds for Cardiac Tissue Engineering. Macromol. Biosci. 2017, 17. [CrossRef] 
118. Zhu, K.; Shin, S.R.; van Kempen, T.; Li, Y.C.; Ponraj, V.; Nasajpour, A.; Mandla, S.; Hu, N.; Liu, X.; Leijten, J.; et al. Gold Nanocomposite Bioink for Printing 3D Cardiac Constructs. Adv. Funct. Mater. $2017,27$. [CrossRef]

119. Lei, Q.; He, J.; Li, D. Electrohydrodynamic 3D printing of layer-specifically oriented, multiscale conductive scaffolds for cardiac tissue engineering. Nanoscale 2019, 11, 15195-15205. [CrossRef]

120. Noor, N.; Shapira, A.; Edri, R.; Gal, I.; Wertheim, L.; Dvir, T. 3D Printing of Personalized Thick and Perfusable Cardiac Patches and Hearts. Adv. Sci. 2019, 6, 1900344. [CrossRef]

121. Cui, Z.; Yang, B.; Li, R.-K. Application of Biomaterials in Cardiac Repair and Regeneration. Engineering 2016, 2, 141-148. [CrossRef]

122. Gorain, B.; Choudhury, H.; Pandey, M.; Kesharwani, P.; Abeer, M.M.; Tekade, R.K.; Hussain, Z. Carbon nanotube scaffolds as emerging nanoplatform for myocardial tissue regeneration: A review of recent developments and therapeutic implications. Biomed. Pharmacother. 2018, 104, 496-508. [CrossRef] [PubMed]

123. Pok, S.; Vitale, F.; Eichmann, S.L.; Benavides, O.M.; Pasquali, M.; Jacot, J.G. Biocompatible carbon nanotube-chitosan scaffold matching the electrical conductivity of the heart. ACS Nano 2014, 8, 9822-9832. [CrossRef] [PubMed]

124. Dvir, T.; Timko, B.P.; Kohane, D.S.; Langer, R. Nanotechnological strategies for engineering complex tissues. Nat. Nanotechnol. 2011, 6, 13-22. [CrossRef] [PubMed]

125. Martins, A.M.; Eng, G.; Caridade, S.G.; Mano, J.F.; Reis, R.L.; Vunjak-Novakovic, G. Electrically conductive chitosan/carbon scaffolds for cardiac tissue engineering. Biomacromolecules 2014, 15, 635-643. [CrossRef]

126. Wu, F.; Gao, A.; Liu, J.; Shen, Y.; Xu, P.; Meng, J.; Wen, T.; Xu, L.; Xu, H. High Modulus Conductive Hydrogels Enhance In Vitro Maturation and Contractile Function of Primary Cardiomyocytes for Uses in Drug Screening. Adv. Healthc. Mater. 2018, 7, e1800990. [CrossRef]

127. Balasubramanian, P.; Prabhakaran, M.P.; Kai, D.; Ramakrishna, S. Human cardiomyocyte interaction with electrospun fibrinogen/gelatin nanofibers for myocardial regeneration. J. Biomater. Sci. Polym. Ed. 2013, 24, 1660-1675. [CrossRef]

128. Kai, D.; Prabhakaran, M.P.; Jin, G.; Ramakrishna, S. Guided orientation of cardiomyocytes on electrospun aligned nanofibers for cardiac tissue engineering. J. Biomed. Mater. Res. B Appl. Biomater. 2011, 98, 379-386. [CrossRef]

129. Ding, M.; Andersson, H.; Martinsson, S.; Sabirsh, A.; Jonebring, A.; Wang, Q.D.; Plowright, A.T.; Drowley, L. Aligned nanofiber scaffolds improve functionality of cardiomyocytes differentiated from human induced pluripotent stem cell-derived cardiac progenitor cells. Sci. Rep. 2020, 10, 13575. [CrossRef]

130. Hussain, A.; Collins, G.; Yip, D.; Cho, C.H. Functional 3-D cardiac co-culture model using bioactive chitosan nanofiber scaffolds. Biotechnol. Bioeng. 2013, 110, 637-647. [CrossRef] 